\title{
Geochemical characteristics of Triassic and Cretaceous phosphorite horizons from the Transdanubian Mountain Range (western Hungary): genetic implications
}

\author{
Zsuzsa Molnár ${ }^{1, *}$, Gabriella B. Kiss ${ }^{1}$, István DunkL ${ }^{2}$, György CZuppon ${ }^{3}$, Federica ZaCCARini ${ }^{4}$ and \\ ISTVÁN DÓDONY ${ }^{1}$ \\ 1 Department of Mineralogy, Eötvös Loránd University, Pázmány P. street 1/C, H-1117 Budapest, Hungary \\ 2 Department of Sedimentology and Environmental Geology, Geoscience Center, University of Göttingen, \\ Goldschmidt street 3, D-37077 Göttingen, Germany \\ 3 Institute for Geological and Geochemical Research, Research Centre for Astronomy and Earth Sciences, Hungarian \\ Academy of Sciences, Budaörsi street 45, H-1112 Budapest, Hungary \\ 4 Department of Applied Geosciences and Geophysics, University of Leoben, Peter Tunner street 5., A-8700 Leoben, \\ Austria
}

[Received 16 January 2017; Accepted 20 December 2017; Associate Editor: Eimear Deady]

\section{ABSTRACT}

The carbonate-dominated Mesozoic sequence of the Transdanubian Mountain Range contains Triassic, uranium-enriched phosphorite layers and Cretaceous, REE-enriched nodular phosphorite. Detailed investigation of these deposits may have an economic benefit because of their large $\mathrm{U}$ and $R E E$ contents. The dominant minerals in the Triassic phosphorite are carbonate-bearing fluorapatite (CFA) and calcite. According to the electron-probe microanalysis (EPMA) the U is mainly associated with the CFA crystals. Laser ablation-inductively coupled plasma-mass spectrometry (LA-ICP-MS) measurement shows that CFA contains 137-612 ppm U and 113-261 ppm total REE + Y. The LA-ICP-MS U-Pb age of the uppermost phosphorite horizon is $237 \pm 11 \mathrm{Ma}$, which conforms with the stratigraphic age of the host limestone.

The Cretaceous nodular phosphorite occurs on the base of an Aptian crinoid-bearing limestone mostly in the form of encrustations around bio- and silicic-clasts, but the clasts also contain phosphorite. The main minerals in these crusts are CFA, calcite, quartz, glauconite and Fe-oxide-hydroxides. Based on EPMA the $R E E$ enrichment is related to CFA and LA-ICP-MS measurements show that it contains 748-2953 ppm total $R E E+\mathrm{Y}$.

The redox-sensitive proxies and the shape of NASC normalized REE patterns indicate that both phosphorites formed in anoxic environments. There are significant differences between these deposits such as appearance, rock-forming minerals, and $\mathrm{U}$ and $R E E$ contents which indicate differences in their sedimentary environments. The present results suggest that the Triassic phosphorite was formed by inorganic precipitation in a reducing environment close to sea-mounts. The Cretaceous occurrence resulted from a concentric growth mechanism in cold, ascending seawater at the continental margin environment during the anoxic Selli Event (OAE 1a) and/or Paquier Episode (OAE 1b). The critical raw material contents were derived from other sources.

*E-mail: molnarzsuzsa89@gmail.com https://doi.org/10.1180/minmag.2017.081.103
KeYwords: U and REE enrichment, phosphorite, carbonate-bearing fluorapatite, Transdanubian Mountain Range.

This paper is part of a special issue entitled 'Critical-metal mineralogy and ore genesis'. The Applied Mineralogy Group of the Mineralogical Society and the IMA Commission on Ore Mineralogy have contributed to the costs of Open Access publication for this paper.

(C) The Mineralogical Society 2018. This is an Open Access article, distributed under the terms of the Creative Commons Attribution licence (http://creativecommons.org/licenses/by/4.0/), which permits unrestricted re-use, distribution, and reproduction in any medium, provided the original work is properly cited. 


\section{Introduction}

PHOSPHORUS is a critical element in many biologically active compounds, an essential nutrient for all living beings. Phosphorite (also referred to as phosphate rock) formations with high concentration of phosphates in nodular or compact masses, contain $\sim 30 \% \mathrm{P}_{2} \mathrm{O}_{5}$ mostly as apatite sensu lato. Most phosphorus $(\sim 80 \%)$ is exploited from sedimentary phosphate deposits and the igneous apatite deposits constitute a less significant source (EC, 2015). Phosphate deposits and occurrences are distributed widely throughout Europe, though in many cases the sizes, origins and chemical compositions of these deposits are unknown. In 2014, phosphate rock was added to the list of critical raw materials (CRMs) for the European Union (EC, 2014). In addition to phosphorous, other CRMs can be recovered from phosphate deposits. Kolodny and Luz (1992) noted several trace elements that substitute for the major elements in the lattice structure, notably the rareearth elements (REEs) (generally 500-2000 ppm, up to $18,000 \mathrm{ppm}$ total $R E E$ content, Baturin and Kochenov, 2001), U (generally 50-200 ppm, up to $3000 \mathrm{ppm}$, Baturin and Kochenov, 2001), Sr and the oxyion, $\mathrm{SO}_{4}^{2-}$. This caused phosphorites to change from a classic agricultural, food technology and chemical resource to a complex critical raw material for high-tech and green technologies.

In the present study, two European phosphorite occurrences, previously unknown (according to the ProMine database (Cassard et al., 2012)) are presented. They are located in the Transdanubian Mountain Range (TDMR), in the ALCAPA Megaunit (ALpine-CArpathian-PAnnonian; Fülöp et al., 1987; Haas et al., 2010).

Phosphorite layers (together with some epigenetic fluorite veins) are located in Triassic limestone and dolomite near the village of Pécsely in the Balaton Highland, in the SW part of the TDMR. The $U$ content of phosphorite has been known since the 1950s (Kiss and Virágh, 1959), but its formation conditions and chemical composition were unclear. Although exploration for $\mathrm{U}$ in the Balaton Highland was intensive in the 1970 s, mining never took place in the area.

Additional samples were taken from the NE part of the TDMR near the city of Tata, where outcrops of Mesozoic, condensed carbonate sequences of the Triassic Dachstein Limestone FormationCretaceous Albian Tata Limestone Formation are found. The phosphorite nodules are found at the base of the Cretaceous sequence (Fülöp, 1975; Szives, 2008). Although the extent of this formation is not significant (i.e. it is unsuitable for mining), understanding its formation process will help in modelling several geologically correlated occurrences throughout Europe.

The aim of the present study was to reveal the details of phosphorite formations in the context of their sedimentary environments and also to evaluate their $\mathrm{U}$ and REE contents and origins. This could contribute to our knowledge about Europe's critical raw material resources.

\section{Geological background}

The Transdanubian Mountain Range (TDMR) is located in western Hungary. It is tectonically part of the ALCAPA Megaunit and bordered by the Rába Line to the northwest, the Diósjenö-Hurbanovo Line to the north and the Balaton Line to the south (Fig. 1). The occurrence near Pécsely is found in the south, whereas Tata is found in the northern part of TDMR. At the beginning of the Mesozoic era, the TDMR was at the rim of the Triassic-Jurassic Neotethys and, subsequently, the Jurassic-Cretaceous Alpine Tethyan rim (Schmid et al., 2008). The arrangement of facies zones indicates that the ALCAPA Megaunit was located between the depositional areas of the Southern Alps and the Northern Calcareous Alps between the Late Paleozoic up to the Palaeogene (Majoros, 1980; Kovács, 1982; Kázmér and Kovács, 1985; Haas et al., 1995; Gawlick et al., 1999; Csontos and Vörös, 2004; Fig. 1).

\section{Geology of the Pécsely area}

The occurrence studied is located in the Öreg Hill, in the middle of the Balaton Highland, between the villages of Pécsely, Vászoly and Örvényes. The Middle Triassic sequence of this area shows unique features because the Pelsonian hemipelagic basinal strata of the Felsöörs Limestone were replaced here by coeval platform carbonates of the Tagyon Formation (Budai and Haas, 1997). This change is explained by synsedimentary extensional tectonics forming isolated carbonate platforms in the area (Budai and Vörös, 1992). As a result of a relative-sea-level rise, the Tagyon Platform was drowned and transformed to a submarine high. This event was followed by deposition of the Upper Anisian-Ladinian basinal carbonate sequence with Late Anisian volcanic tuff interactions and phosphorite horizons on the top of the submarine high (Budai and Haas, 1997; Budai and Vörös, 2006). Based on data of the uranium-exploration project 


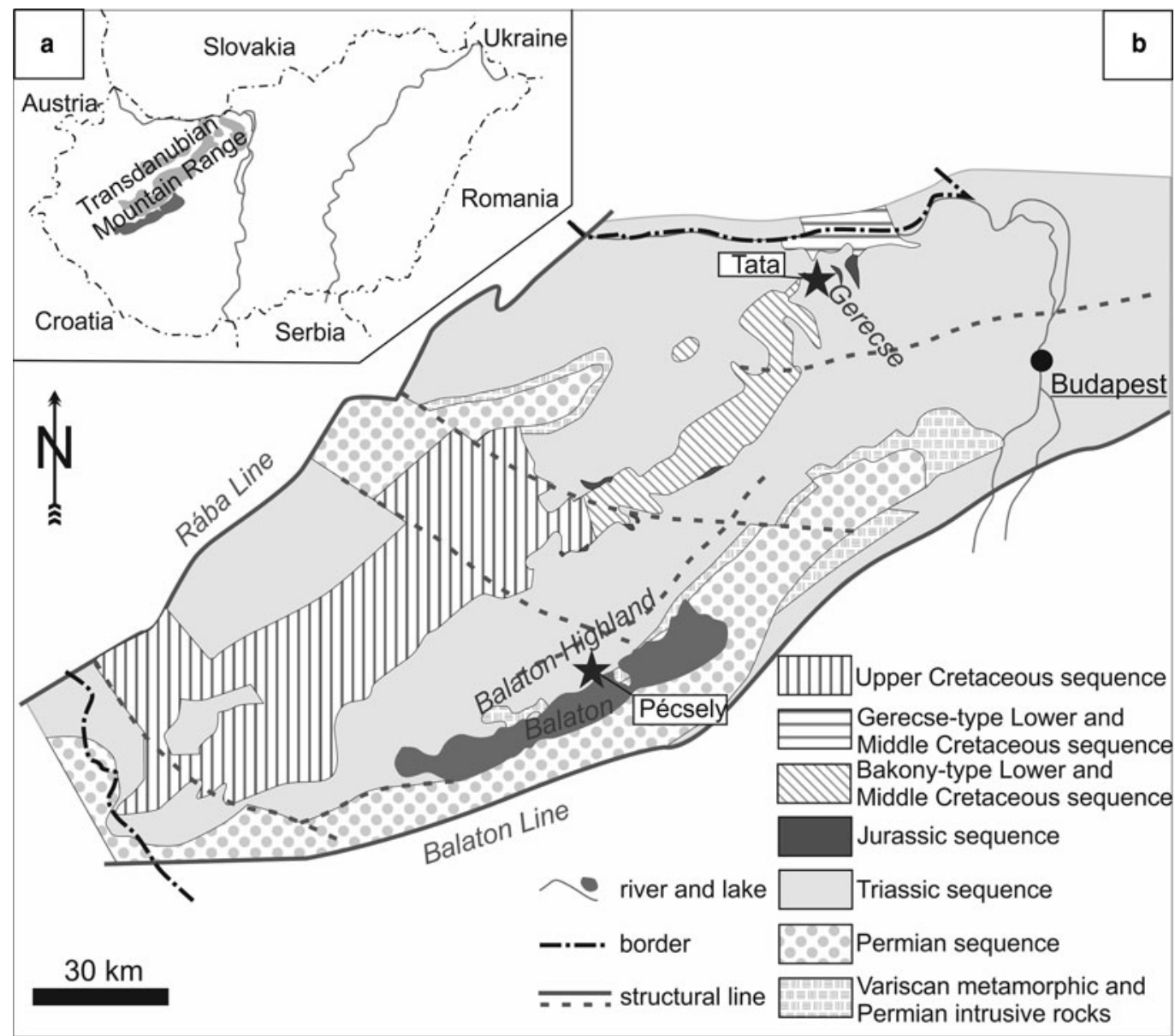

FIG. 1. (a) Location of the Transdanubian Mountain Range; (b) geological map of the Transdanubian Mountain Range with the main structural lineaments (Fülöp et al., 1987; Haas et al., 2010). The localities studied are marked with asterisks.

and the geological mapping (Budai et al., 1999), phosphorites are known only from the northeastern margin of the Tagyon High (Fig. 2).

The brownish-grey U-bearing phosphorite layers of the Upper Illyrian sequence of the Öreg Hill appear in three stratigraphic horizons. The lowermost horizon occurs at the drowning surface of the Tagyon Formation and the overlying tuffaceous carbonate beds of the Vászoly Formation. The upper section occurred after the formation of reddish or purple organic-rich limestone of the lower member of the Vászoly Formation. The uppermost phosphorite horizon occurs in the form of a dark, greenish-grey crust on the bedding-surface of the bedded Vászoly Formation. The thicknesses of these irregular phosphoritic bodies vary, even over short distances, by up to $1.2 \mathrm{~m}$. The stratigraphical and structural cross section of the Öreg Hill was constructed (Fig. 3; Budai, 1993; Budai et al., 1999) from sections of the Pécsely P-5 borehole and P-11/a trench (Kiss and Virágh, 1959; Vörös and Pálfy, 1989) and detailed geological mapping (Budai and Dosztály, 1990).

The main mineral of the deposit is carbonate fluorapatite (Kiss and Virágh, 1959), formed in shallow-marine conditions where the accumulation of phosphorous was aided by organisms (brachiopods, crinoids, bacteria and algae); the phosphorous content was then compressed diagenetically into a deposit. Kiss and Virágh (1959) suggested that the $\mathrm{U}$ content of the rock was probably the result of concentration from older rocks, e.g. Permian sandstone. The zircon crystals and the $U$ content could have been derived from primary deposits related to a primary alkaline magma, however. 


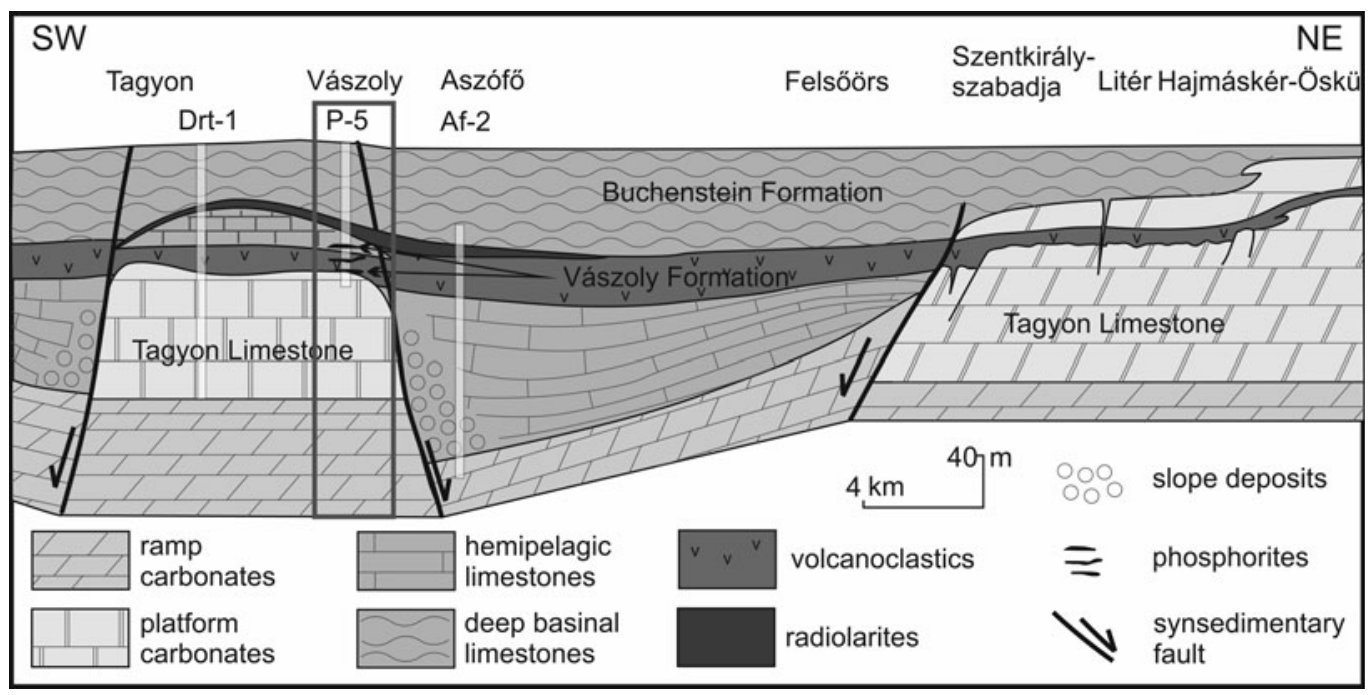

FIG. 2. Facies arrangement of Middle Triassic Formations, along strike, of the Balaton Highland (after Budai and Vörös, 2006). The formations found in the area of Pécsely are marked with a grey rectangle.

\section{Geology of the Tata area}

The Mesozoic layers at the Kálvária Hill at Tata form an uplifted block, surrounded by Oligocene fluvial and Miocene lacustrine deposits (Korpás, 1981; Tari et al., 1993; Fig. 4).

The quarry at the Kálvária Hill, exposes a condensed Upper Triassic-Lower Cretaceous, mostly carbonate-dominated succession. At the base of the Cretaceous layers, phosphatized and slightly glauconitic fossils, phosphorite nodules, plant remnants and small, rounded black pebbles accumulated in erosional pockets (Fülöp, 1975; Szives, 2008). These phosphorite crusts are composed of sloping, thin $(1 \mathrm{~mm}-50 \mathrm{~cm})$ bands of various compositions: calcite, apatite, glauconite and limonite-bearing material (Fülöp, 1975). The bedrock of the phosphorite investigated is the

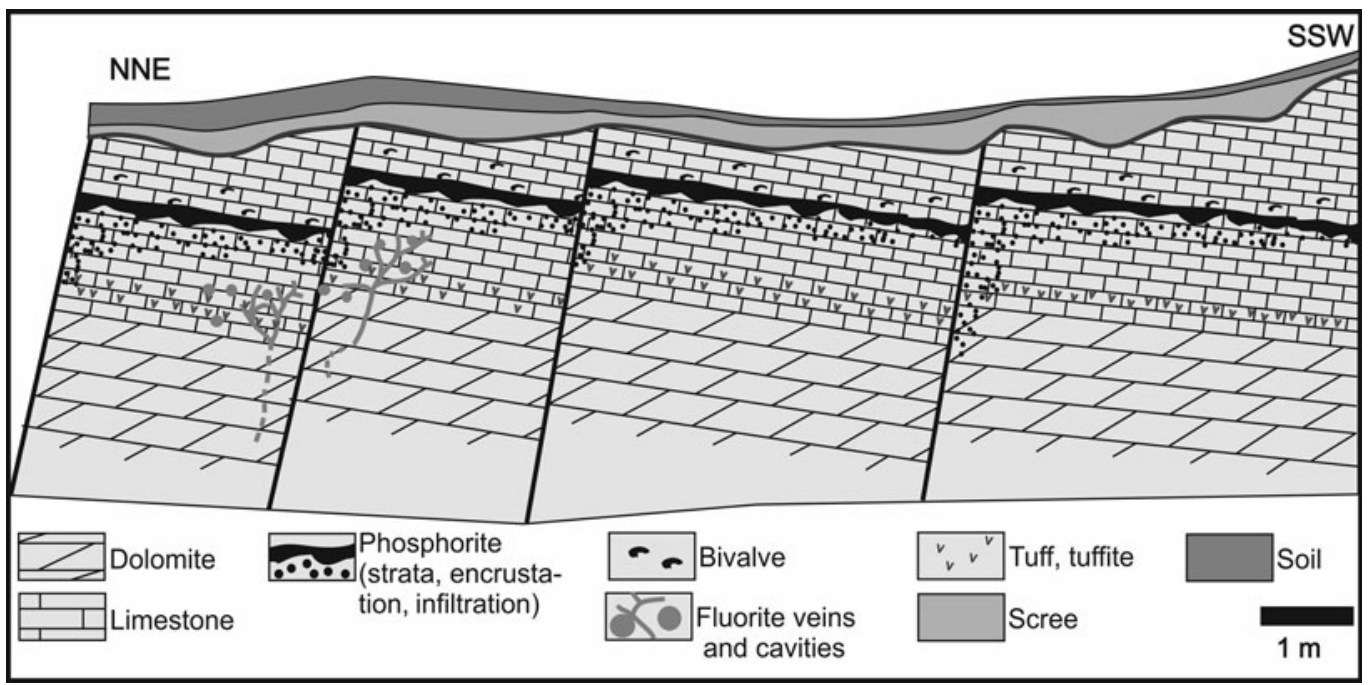

FIG. 3. Schematic geological section of the Pécsely-11 exploration trench (modified after Kiss and Virágh, 1959). 


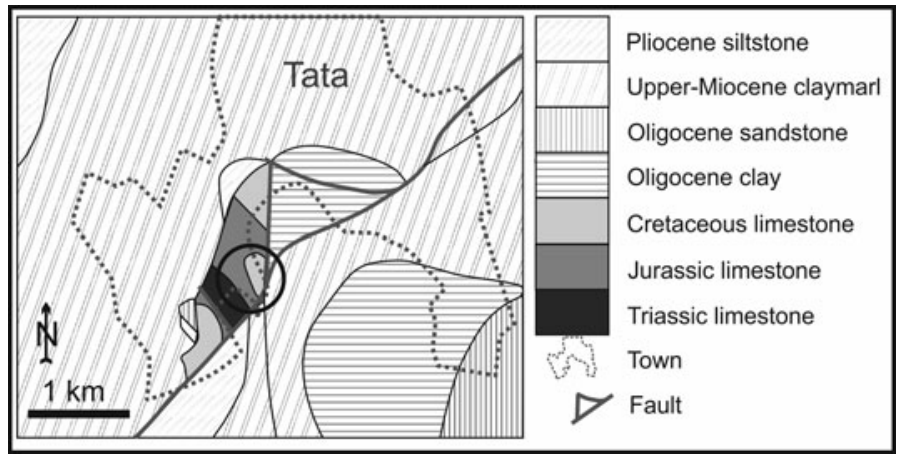

Fig. 4. Pre-Quaternary geological map of the Tata area (Balla et al. 2009). The location of the Kálvária Hill is indicated by a black circle.

Szentivánhegy Limestone Formation (Fig. 5a), which is a thin bedded, clayey limestone with a light pinkish-grey colour. The fossils indicate that

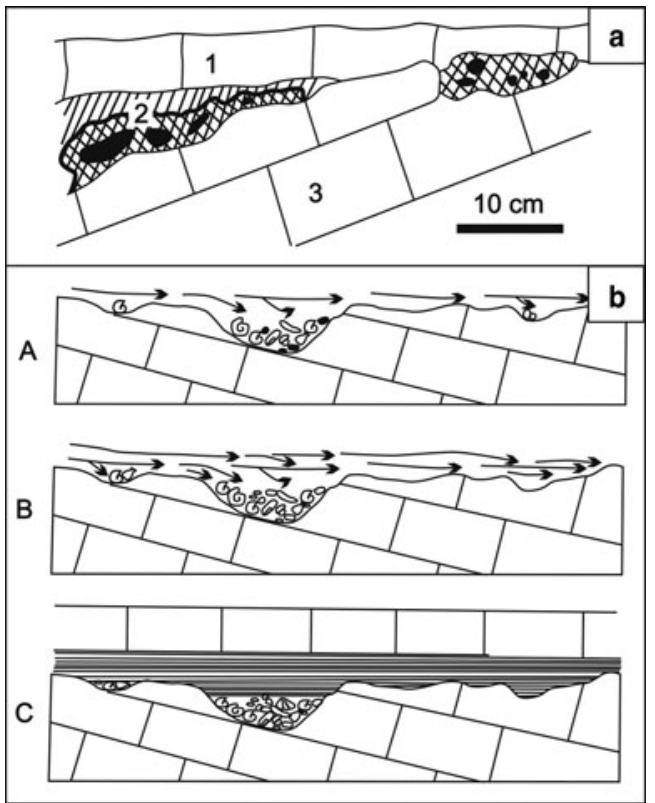

FIG. 5. (a) Location of the fossil and phosphorite-bearing hardground of Tata (2) between the Valanginian bedrock (3) and the Aptian cover rock (1); (b) hypothetical model for the preservation of the condensed basal beds at Kálvária Hill. Bottom flows accumulated fossils in the traps of the underlying hardground (A), the turbulence which occurred in the traps mixed the succession constantly (B) until the whole hollow was covered with the basal, marly beds of the Tata Limestone (C) (after Fülöp, 1975; Szives, 2001). these layers were formed in a deep bathyal, basinal environment during the Tithonian-Valanginian (Fülöp, 1975; Fözy, 2012, 2013). The cover sequence is the Cretaceous crinoidal Tata Limestone Formation of Aptian-Albian age. This glauconitic, extraclast-rich limestone is grey, yellowish grey, greenish grey in colour. Here, the fossils show that this sequence formed in a sublitoral, external shelf or seamount and/or shallow-marine environment (Fülöp, 1954, 1964, 1975; Knauer et al., 1972; Sidó, 1975; Haas et al., 1985; Lelkes, 1990; Császár, 1995; Szives, 1999, 2001; Pocsai and Csontos, 2006). Fülöp (1975) described the phosphorite occurring at the basal layer of the Tata Limestone Formation as a stromatolite, based on its appearance. That author suggested that it formed in the tidal zone and that the phosphate-bearing material surrounded the siliciclasts and the organic residuals also. According to several other studies, however, this erosional gap was caused by orogenesis related to the closure of the southern part of the Penninic Ocean which closed the Albian-Cenoman layers (Vadász, 1946; Bárdossy, 1982; Mindszenty, 1984).

\section{Analytical methods}

Samples were collected from Öreg Hill at Pécsely (N46 $\left.55^{\prime} 50^{\prime \prime} \mathrm{E} 17^{\circ} 47^{\prime} 00^{\prime \prime}\right)$ and Kálvária Hill at Tata

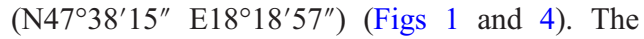
petrography of the samples collected was carried out on standard polished thin sections representing both the host rock and the phosphorite, using Nikon Alphaphot and Zeiss Axioplan polarizing microscopes. Powder X-ray diffraction (PXRD) using a Siemens D-5000 type diffractometer was applied to determine the mineral phases. The parameters of 
data acquisition: Bragg-Brentano geometry $(\theta-\theta$ mode, $\mathrm{CuK \alpha}(\lambda=0.154178 \mathrm{~nm} 40 \mathrm{kV}, 30 \mathrm{~mA})$, secondary graphite crystal monochromator, and scintillation detector). Evaluation of the PXRD patterns used EVA software. All the above-mentioned analyses were carried out at the Department of Mineralogy, Eötvös Loránd University, Budapest.

For compositional and textural measurements a scanning electron microscope equipped with an energy dispersive spectrometer at the Department of Petrology and Geochemistry, Eötvös Loránd University was used on an AMRAY 1830 SEM + EDS instrument, with an accelerating voltage of $20 \mathrm{kV}$ and a $1 \mathrm{nA}$ beam current. These compositions are qualitative.

Quantitative electron microprobe analyses of apatite and elemental mapping were completed in the Eugen F. Stumpfl Microprobe Laboratory of the University of Leoben with a JEOL Superprobe JXA 8200 type electron microprobe. Wavelength dispersive mode was used with an accelerating voltage of $15 \mathrm{kV}$ and a $10 \mathrm{nA}$ beam current; the detection limits are shown in Table 1.

Bulk-rock ICP-MS (for trace elements) with an ELAN DRC II mass spectrometer were carried out in the Geological and Geophysical Institute of Hungary. Lithium borate was used to fuse the samples. The detection limits and analytical procedures are described in the accreditation documentation of the laboratory (accreditation number: NAT-1-1302/2012).

The in situ U-Pb dating and trace-element determinations of apatite was performed by laserablation single-collector sector-field inductively coupled plasma mass spectrometry using a Thermo Finnigan Element 2 instrument in the GÖochron Laboratories, Göttingen. The method employed for analysis is described in detail by Frei and Gerdes (2009). All age data presented here were obtained by single-spot analysis using a laser beam diameter of $33 \mu \mathrm{m}$ and a crater depth of $\sim 10 \mu \mathrm{m}$. The laser was fired at a repetition rate of 5. Two laser pulses were used for pre-ablation. The carrier gas was $\mathrm{He}$ and $\mathrm{Ar}$. Analyses of ${ }^{238} \mathrm{U},{ }^{235} \mathrm{U},{ }^{232} \mathrm{Th},{ }^{208} \mathrm{~Pb},{ }^{207} \mathrm{~Pb},{ }^{206} \mathrm{~Pb}$, mass 204 and ${ }^{202} \mathrm{Hg}$ were measured by the ICP-MS. The data reduction involved processing of $\sim 50$ selected time slices starting $\sim 3 \mathrm{~s}$ after the beginning of the signal. The age calculation and quality control are based on the drift- and fractionation-correction by standard-sample bracketing using GJ-1 zircon reference material (Jackson et al., 2004). For further control the Plešovice zircon (Sláma et al., 2008), the 91500 zircon (Wiedenbeck et al., 1995) and the FC-1 zircon (Paces and Miller, 1993) were analysed as 'secondary standards'. The age results of the standards were consistently within $2 \sigma$ of the published ID-TIMS values. Drift and fractionation corrections and data reductions were performed using our in-house software (UranOS; Dunkl et al., 2008). The concordia plot was constructed by the Isoplot/Ex 3.0 spreadsheet (Ludwig, 2012). The laser ablation-based trace-element concentrations were determined by similar instrumental settings, the standard reference materials were NIST 610 and 612 glasses.

Measured REE-Y abundances were normalized against North American Shale Composite (NASC; Haskin and Haskin 1966; Gromet et al., 1984). NASC-normalized values are marked with the subscript ' $N$ '. Anomalies are quantified ratios of measured and calculated values of a given element, and an asterisk denotes estimated values calculated using the geometric mean of the neighbouring elements following the convention of McLennan (1989): $\mathrm{Ce} / \mathrm{Ce} *=\mathrm{Ce}_{\mathrm{N}} /\left(\mathrm{La}_{\mathrm{N}} \times \operatorname{Pr}_{\mathrm{N}}\right)^{0.5}, \mathrm{Pr} / \mathrm{Pr}^{*}=\mathrm{Pr}_{\mathrm{N}} /$ $\left(\mathrm{Ce}_{\mathrm{N}} \times \mathrm{Nd}_{\mathrm{N}}\right) 0.5, \mathrm{Eu} / \mathrm{Eu}^{*}=\mathrm{Eu}_{\mathrm{N}} /\left(\mathrm{Sm}_{\mathrm{N}}^{0.67} \times \mathrm{Tb}_{\mathrm{N}}^{0.33}\right)$.

The stable carbon and oxygen isotope measurements of carbonate samples were carried out at the Institute for Geological and Geochemical Research, Research Centre for Astronomy and Earth Sciences, Hungarian Academy of Sciences. In situ sampling was performed using an electric drill with a bit diameter of $0.6 \mathrm{~mm}$. The resulting 150-200 $\mu \mathrm{g}$ samples were subjected to stable carbon and oxygen isotope analyses by carbonateorthophosphoric acid reaction at $72^{\circ} \mathrm{C}$ (Spötl and Wennemann, 2003) and using an automated GASBENCH II sample preparation device attached to a Thermo Finnigan Delta Plus XP mass spectrometer. The isotope compositions are expressed as $\delta^{13} \mathrm{C}$ and $\delta^{18} \mathrm{O}$ in parts per thousand (per mil) (\%o) relative to V-PDB (Vienna Pee Dee Belemnite $)$, according to the equation: $\delta=\left(R_{\text {sample }} /\right.$ $\left.R_{\text {standard }}-1\right) \times 1000$, where $R$ is the ${ }^{13} \mathrm{C} /{ }^{12} \mathrm{C}$ or ${ }^{18} \mathrm{O} /{ }^{16} \mathrm{O}$ ratio in the sample or in the international standard. The precision was better than $0.15 \%$ for $\mathrm{C}$ and $\mathrm{O}$ isotope data, based on replicate measurements of international standards (NBS-19; NBS18 ) and in-house reference materials.

\section{Results}

\section{Petrography}

\section{The Triassic strata at Pécsely}

The authors collected samples from all three horizons (Fig. 6a). The colour and bioclast content of host rock is variable; the textures 
TABLE 1. Results of the EPMA of the selected CFA grains from the Triassic and Creataceous phosphorite occurrences.

\begin{tabular}{|c|c|c|c|c|c|c|c|c|c|c|c|c|c|}
\hline & \multicolumn{9}{|c|}{ Major elements distribution (wt.\%) } & \multirow[b]{2}{*}{ Total } & \multicolumn{3}{|c|}{ Calculated composition } \\
\hline & $\mathrm{CaO}$ & $\mathrm{P}_{2} \mathrm{O}_{5}$ & $\mathrm{~F}$ & $\mathrm{Cl}$ & $\mathrm{SiO}_{2}$ & $\mathrm{MgO}$ & $\mathrm{FeO}$ & $\mathrm{MnO}$ & $\mathrm{SO}_{3}$ & & $\mathrm{CO}_{2}$ & $\mathrm{OH}$ & $\mathrm{Na}_{2} \mathrm{O}$ \\
\hline Detection limit & 0.02 & 0.02 & 0.04 & 0.01 & 0.02 & 0.01 & 0.02 & 0.02 & 0.04 & & & & \\
\hline Pécsely-1 & 52.71 & 31.60 & 6.26 & 0.02 & 0.02 & 0.07 & b.d.l. & 0.03 & 1.42 & 92.14 & 4.03 & 2.96 & 0.88 \\
\hline Pécsely-2 & 52.14 & 25.17 & 6.08 & 0.01 & b.d.l. & 0.06 & b.d.l. & 0.03 & 1.58 & 85.06 & 11.94 & 1.97 & 1.04 \\
\hline Pécsely-3 & 52.00 & 29.00 & 5.97 & 0.03 & 0.02 & 0.07 & 0.03 & b.d.1. & 1.62 & 88.74 & 7.15 & 3.03 & 1.08 \\
\hline Pécsely-4 & 48.57 & 28.71 & 5.95 & 0.02 & 4.63 & 0.14 & 0.41 & b.d.1. & 1.71 & 90.14 & 4.09 & 3.87 & 1.91 \\
\hline Pécsely-5 & 52.95 & 29.41 & 6.27 & 0.01 & b.d.l. & 0.07 & 0.05 & b.d.l. & 1.76 & 90.51 & 6.58 & 2.10 & 0.81 \\
\hline Pécsely-6 & 51.45 & 29.16 & 6.68 & 0.03 & b.d.1. & 0.12 & b.d.l. & b.d.1. & 1.39 & 88.83 & 7.10 & 2.86 & 1.21 \\
\hline Pécsely-7 & 51.08 & 28.59 & 6.71 & 0.02 & b.d.l. & 0.11 & 0.03 & b.d.l. & 1.25 & 87.79 & 7.88 & 3.02 & 1.31 \\
\hline Pécsely-8 & 52.31 & 29.58 & 6.55 & 0.03 & 0.04 & 0.10 & 0.06 & b.d.l. & 1.65 & 90.31 & 6.40 & 2.32 & 0.97 \\
\hline Pécsely-9 & 53.76 & 30.79 & 6.60 & 0.03 & 0.26 & 0.07 & 0.04 & b.d.l. & 1.36 & 92.90 & 4.90 & 1.61 & 0.59 \\
\hline Pécsely-11 & 53.10 & 30.30 & 7.25 & 0.02 & 0.12 & 0.08 & 0.04 & b.d.l. & 1.35 & 92.25 & 5.61 & 1.37 & 0.77 \\
\hline Pécsely-12 & 51.92 & 31.61 & 7.86 & b.d.1. & 0.34 & 0.04 & b.d.1. & b.d.1. & 1.26 & 93.03 & 3.88 & 1.98 & 1.11 \\
\hline Pécsely-13 & 52.39 & 31.07 & 6.64 & 0.01 & 0.76 & 0.05 & b.d.l. & 0.02 & 1.76 & 92.69 & 3.96 & 2.37 & 0.98 \\
\hline Tata-1 & 47.12 & 29.81 & 5.09 & b.d.1. & 7.19 & 0.27 & 3.00 & b.d.1. & 0.68 & 93.16 & 1.41 & 3.73 & 1.71 \\
\hline Tata-3 & 47.54 & 32.24 & 4.70 & 0.01 & 4.06 & 0.30 & 2.58 & 0.03 & 0.67 & 92.12 & 0.70 & 5.51 & 1.67 \\
\hline Tata-5 & 49.42 & 32.91 & 4.89 & b.d.1. & 3.94 & 0.29 & 2.16 & 0.06 & 0.65 & 94.32 & 0.00 & 4.45 & 1.23 \\
\hline Tata-6 & 45.77 & 29.65 & 4.62 & b.d.l. & 8.42 & 0.56 & 3.17 & b.d.1. & 0.65 & 92.83 & 0.72 & 4.51 & 1.93 \\
\hline Tata-7 & 54.62 & 32.33 & 4.29 & b.d.l. & 5.02 & 0.08 & 0.59 & b.d.l. & 0.49 & 97.42 & 0.00 & 2.36 & 0.22 \\
\hline Tata-8 & 52.68 & 35.98 & 5.18 & b.d.1. & 4.00 & 0.18 & 1.53 & 0.05 & 0.65 & 100.24 & 0.00 & 0.00 & 0.51 \\
\hline Tata-9 & 52.19 & 35.30 & 4.34 & b.d.l. & 2.77 & 0.13 & 2.41 & 0.03 & 0.56 & 97.72 & 0.00 & 1.80 & 0.48 \\
\hline Tata-10 & 52.68 & 36.35 & 4.90 & 0.01 & 0.78 & 0.10 & 1.84 & 0.03 & 0.49 & 97.18 & 0.00 & 2.35 & 0.47 \\
\hline Tata-11 & 50.72 & 34.13 & 5.09 & 0.01 & 3.86 & 0.23 & 0.99 & 0.04 & 0.51 & 95.56 & 0.00 & 3.29 & 1.15 \\
\hline
\end{tabular}

b.d.1.: below detection limit 

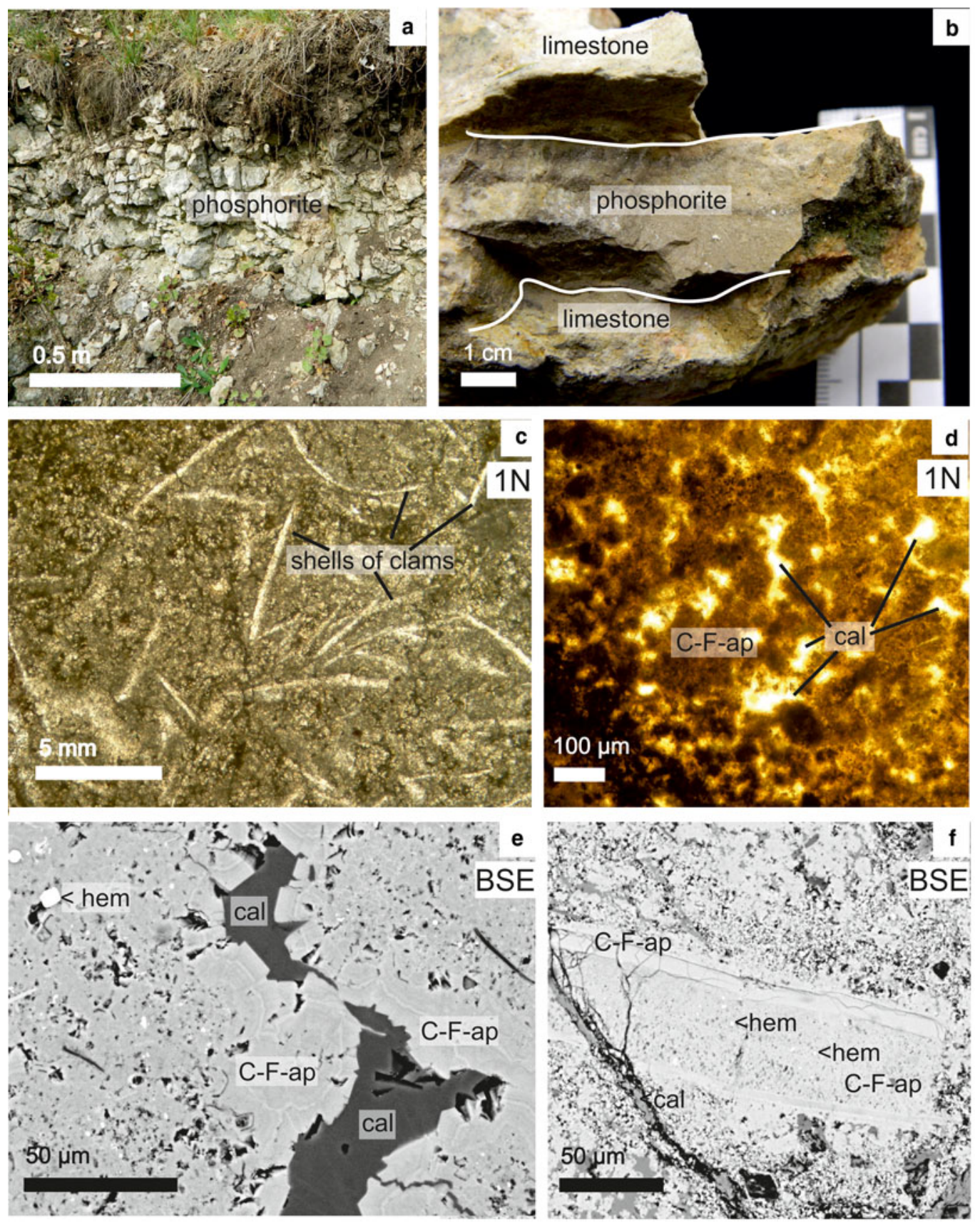

FIG. 6. (a) The lowermost phosphorite layer; (b) pelagic limestone with a phosphorite layer; $(c)$ photomicrograph of the host rock which contain thin-shell remains of clams and a bio-apatite matrix; $(d)$ photomicrograph of the U-bearing phosphorite layer; (e) BSE image of the layer studied; fine zonation of the carbonate-bearing fluorapatite crystals is visible. The original crystal size was not large; they are typically rod-shaped, with round terminations and sub-circular cross sections. With ageing, apatite shows better crystallinity; $(f)$ Rare, small bone pieces in the phosphorite (C-F-ap: carbonate-bearing fluorapatite; cal: calcite; hem-hematite). 
suggest that the phosphorite horizons formed syngenetically with the deposition of the limestone. The phosphorite layers are finely zoned which may have been caused by the organic matter content (Fig. 6b). In many cases shrinkage cracks are observed on the surface of the phosphorite beds. These areas are sometimes brecciated, where the clasts are of phosphorite and limestone; the matrix is of phosphorite. In addition the phosphorite also occurs as cement to brecciated dolomite. Apatite is the main component with some calcite and rare hematite, pyrite and zircon. Powder X-ray diffraction (PXRD) studies indicate that the apatite is fluorapatite and that some fluorite may also be present, although fluorite was noted either by the petrographic or by the EPMA (Fig. 7a). The apatite is probably fluorapatite, but no information was obtained regarding the carbonate content.

The host limestone is dolomitized locally with many patches of hematite/limonite and brownish bitumen. The texture of the limestone is micritic and microsparitic, with thin shells and pellets (Fig. 6c). The limestone is cross-cut by calcite veins that do not exceed $1 \mathrm{~cm}$ in thickness. At the margin of veins, 'corroded' calcite with hematite inclusions $(<0.5 \mathrm{~mm})$ can be observed, while the remaining space is filled by equigranular calcite $(0.5-2 \mathrm{~mm})$.

The apatite surrounds the grains of calcite and the remaining space is filled by a later generation of calcite cement (Fig. 6d). The crystal size of the apatite is $<50 \mu \mathrm{m}$, but the crystals are typically rodshaped, with round terminations and subcircular

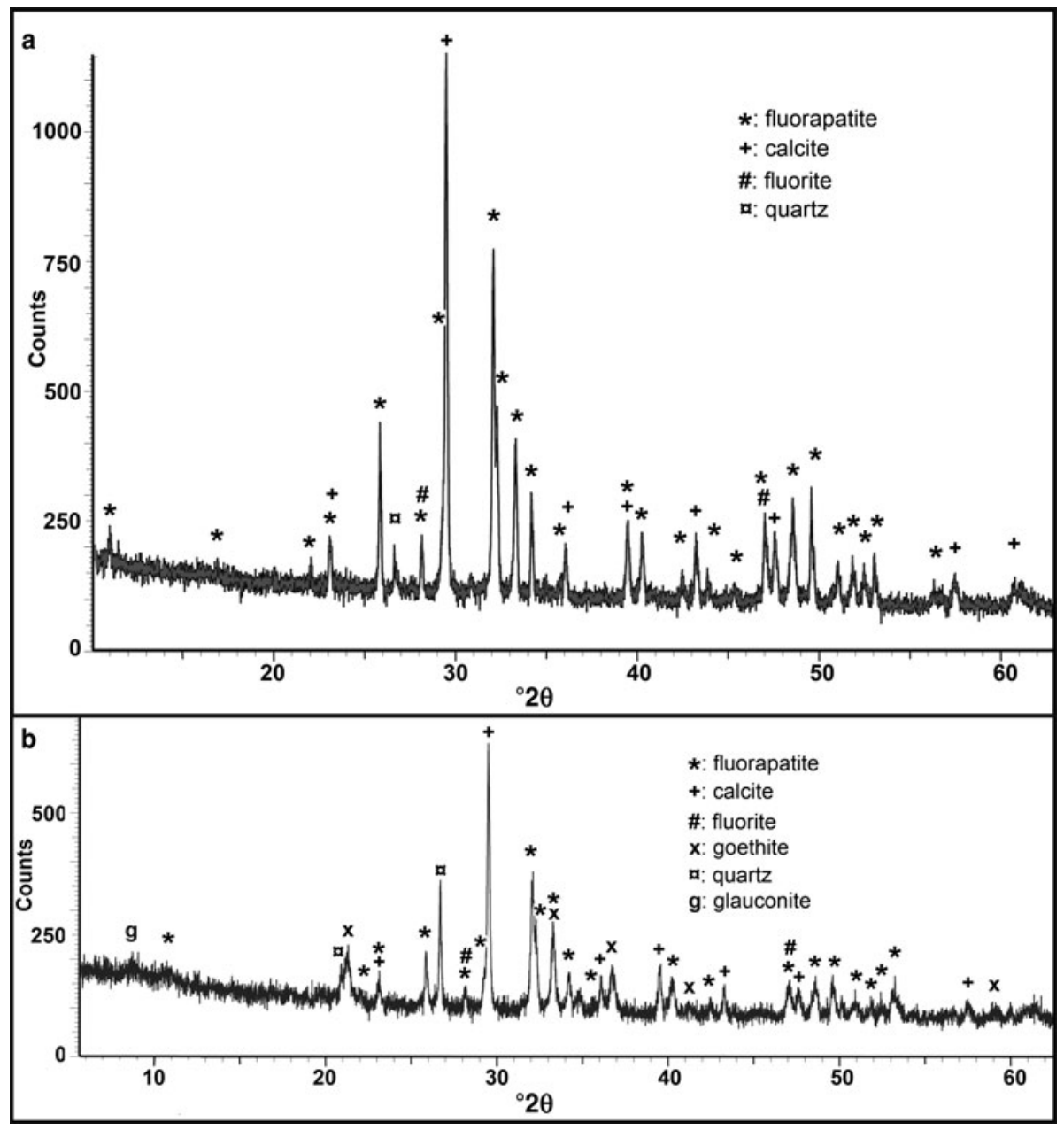

FIG. 7. PXRD spectra of the layered Triassic $(a)$ and the nodular Cretaceous $(b)$ phosphorites. 
cross-sections. On the BSE image a fine-zonation of the CFA crystals is visible (Fig. 6e) although no corresponding compositional changes were detected by EPMA mapping. The first-generation calcite is typically not transparent, while the later one has more transparency and fills the remaining spaces. In many cases phosphorite coating the calcitic bioclasts is observed. In some cases small bone fragments can be found in the phosphorite (Fig. $6 f$ ).

\section{The Cretaceous phosphorite at Tata}

The phosphorite occurring at the base of the Tata Limestone Formation looks like a stromatolite with ochre yellow and pale green colour (Fig. 8a). The occurrence is visible on the surface and strongly

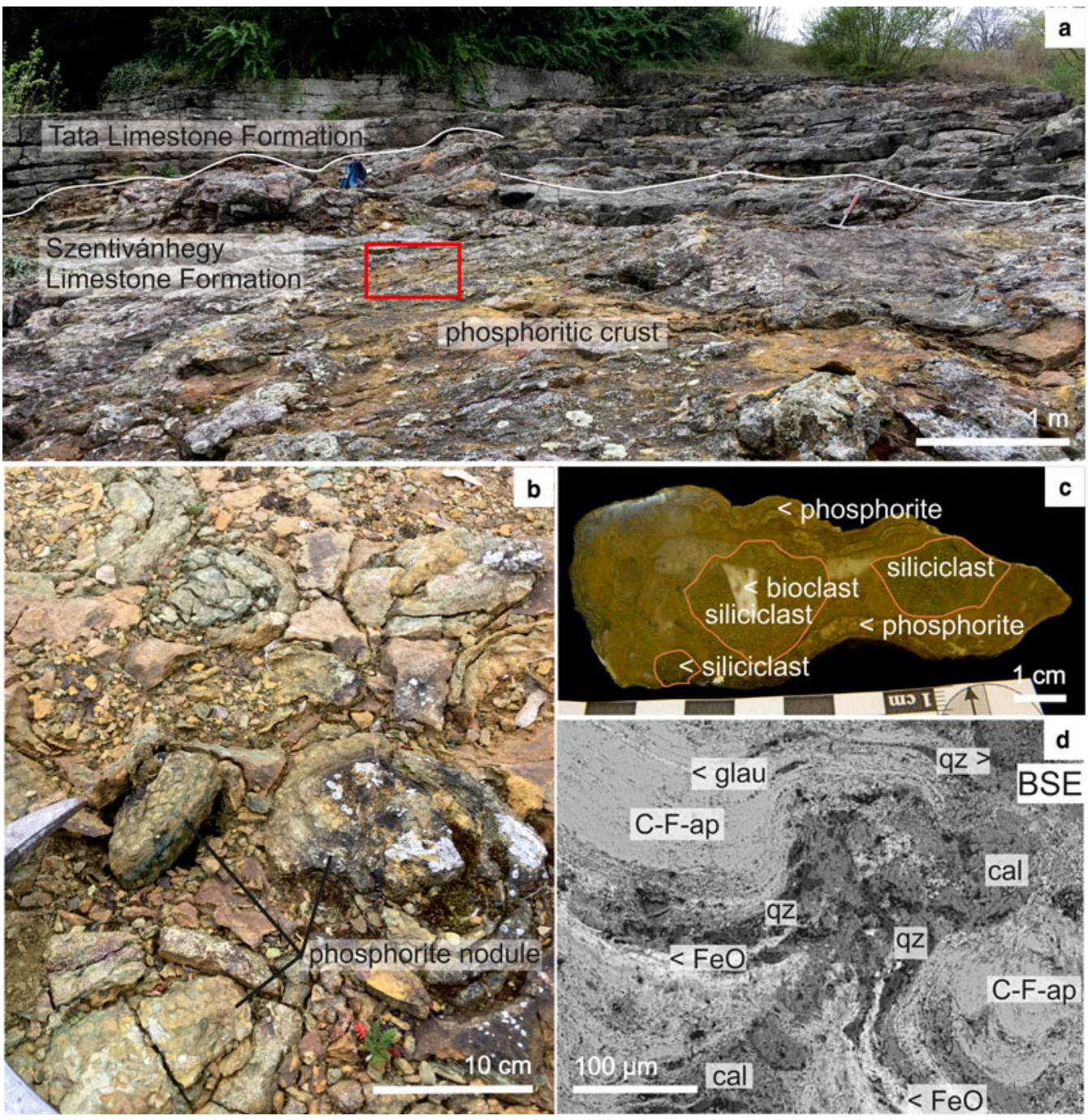

FIG. 8. (a) Outcrop at the Kálvária Hill in Tata. The white line indicates the unconformity between the Szentivánhegy and Tata Formations; $(b)$ Well preserved phosphorite nodules in the centre of the stromatolite structure (the rectangle in part $a$ indicates the location of this image); (c) Polished hand specimen of a Cretaceous phosphorite nodule from Tata. The main minerals of the crust around the calcite-cemented white bio- and greenish-grey siliciclastic material are apatite, calcite, glauconite and goethite. $(d)$ BSE image of the texture of the phosphorite, with visible minerals and the rhythmicity of the layers. (C-F-ap: carbonate-bearing fluorapatite, cal: calcite, FeO: Fe-oxide-hydroxide, glau: glauconite, qz: quartz). 
weathered, but the nodules within are well preserved (Fig. 8b). The well preserved central nodules are spherical and very variable in size, up to $10 \mathrm{~cm}$ across (Fig. $8 b$ ). The centres of the nodules are heterogeneous and contain greenishgrey sandstone clasts (up to $3 \mathrm{~cm}$ ) with white bioclasts (Fig. 8c), or other clasts, e.g. chert, organic residuals. The phosphorite crust is finely laminated $(0.1-0.5 \mathrm{~mm})$ with darker, sometimes rhythmically banded lamellae (Fig. 8c).

Petrographic and PXRD studies show that the main minerals of the crust are fluorapatite, calcite, goethite, quartz and minor amounts of fluorite (Fig. 7b). SEM-EDS examination shows that the calcite-rich layers consist of roundish crystals (30$100 \mu \mathrm{m})$ while the apatite-rich layers are fine grained $(<10 \mu \mathrm{m})$. Fe-oxide or -hydroxide coatings with infrequent hematite, quartz and glauconite are present in both types of layers (Fig. 8d). On the basis of the PXRD studies, apatite is probably fluorapatite.

\section{Age and geochemistry}

Laser ablation $\mathrm{U}-\mathrm{Pb}$ geochronology gave an age of $237 \pm 11$ Ma for the uppermost Triassic phosphorite horizon, which is close to the Anisian-Ladinian age of sedimentation (Fig. 9). This indicates that the $\mathrm{U}-\mathrm{Th}-\mathrm{Pb}$ isotope system of the phosphorite has not been affected by post-depositional fluids and the present trace-element abundances probably reflect the original values. This is remarkable, as the sample site at Pécsely is close to major Eoalpine thrusts (Budai et al., 1999) and the phosphorite is cross-cut by epigenetic fluorite veinlets.

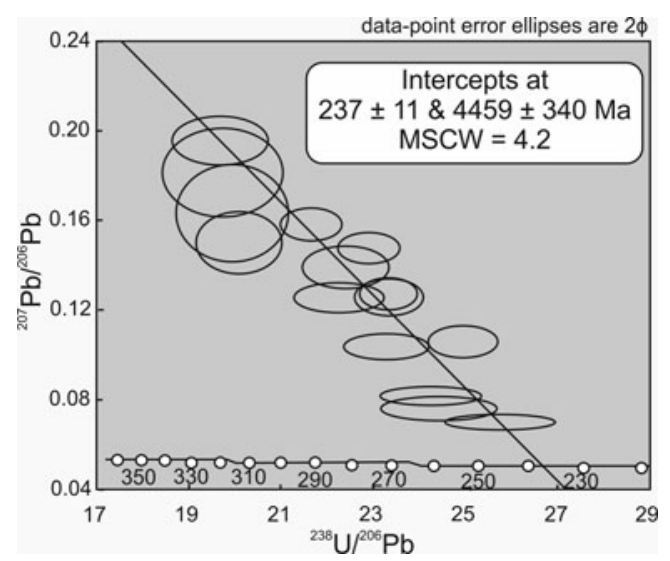

FIG. 9. Tera-Wasserburg plot of the LA-ICP-MS U-Pb spots of the Triassic phosphorite from Pécsely.
The low, $20 \mathrm{ppm} \mathrm{U}$ content and the high (99\%) common $\mathrm{Pb}$ ratio made it impossible to perform $\mathrm{U}-\mathrm{Pb}$ geochronology on the Cretaceous phosphorite.

The EPMA results of apatite obtained were characterized by low totals and in many cases there was a high excitation crater at the site of measurement. These phenomena refer to the high volatility of the samples. The formula was calculated, therefore, as carbonate-bearing fluorapatite, which is also in good agreement with the findings of Kiss and Virágh (1959). Calculations based on the quantitative EPMA (Table 1) of the apatite from Pécsely produced the formula: $\left(\mathrm{Na}_{0.57} \mathrm{Ca}_{4.43}\right)_{5}\left[\left(\mathrm{PO}_{4}\right)_{2.44}\left(\mathrm{CO}_{3}\right)_{0.56}\right]_{3} \mathrm{~F}$ which is clearly a carbonate-bearing fluorapatite (CFA) (Palache et al., 1951). The crystals contain 88$201 \mathrm{ppm}$ REE and 137-612 ppm U. Element mapping showed that of $U$ and $R E E$ are distributed homogeneously in the CFA crystals and no other U-bearing phases were observed. The EPMA (Table 1) showed that the main mineral in the Tata phosphorite crusts is also carbonate-bearing fluorapatite with a formula of $\left(\mathrm{Na}_{0.34} \mathrm{Ca}_{4.66}\right)_{5}$ $\left[\left(\mathrm{PO}_{4}\right)_{2.66}\left(\mathrm{CO}_{3}\right)_{0.34}\right]_{3} \mathrm{~F}$ and the element mapping again showed that the REE are distributed homogeneously. The REE concentrations are 6432569 ppm but the $U$ content is lower $(<26 \mathrm{ppm} \mathrm{U})$.

Bulk-rock samples from Pécsely contain total $R E E+\mathrm{Y}$ of 116-158 ppm (Table 2). Normalized to the North American Shale Composite the Triassic phosphorite is slightly depleted with negative $\mathrm{Ce}$ and $\mathrm{Eu}$ anomalies (Fig. 10a). At Tata the total $R E E+\mathrm{Y}$ content is $1055 \mathrm{ppm}$ with a similar $R E E$ distribution pattern to that observed at Pécsely. However, the Cretaceous phosphorite is enriched relative to NASC with positive $\mathrm{Ce}$ and $\mathrm{Eu}$ anomalies (Fig. 10a).

Redox sensitive proxies like $\mathrm{Th} / \mathrm{U}, \mathrm{V} / \mathrm{Sc}, \mathrm{V} / \mathrm{Cr}$ and $\mathrm{Ni} / \mathrm{Co}$ ratios of $\mathrm{CFA}$ are used to characterize the sedimentary environment (Jones and Manning, 1994; Kimura and Watanabe, 2001; Rimmer, 2004; Tables 2 and 3). The Th/U ratio is always $<0.04$ in the samples from Pécsely, but ranges from 0.9 to 1.7 in the samples from Tata. The enormous differences between these values from the two areas are caused by $\mathrm{U}$ enrichment at Pécsely. The $\mathrm{V} / \mathrm{Sc}$ ratio of the phosphorite from Pécsely ranges from 66 to 643, but is between 31 and 112 at Tata. The $\mathrm{V} / \mathrm{Cr}$ ratio ranges from 9.6 to 37 in the case of Pécsely and from 0.7 to 25.4 at Tata. The Ni/Co ratio ranges from 1.6 to 58 in the Pécsely samples, while the same ratio is from 6.5 to 13.5 in the Tata samples. The correlation coefficient between Th-U and Th-V 
TABLE 2. REE content (ppm) and redox-sensitive element ratios of the phosphorites studied.

\begin{tabular}{|c|c|c|c|c|c|c|c|c|c|c|c|c|c|c|c|c|c|c|}
\hline Sample & $\mathrm{La}$ & $\mathrm{Ce}$ & $\operatorname{Pr}$ & $\mathrm{Nd}$ & $\mathrm{Sm}$ & $\mathrm{Eu}$ & $\mathrm{Gd}$ & $\mathrm{Tb}$ & Dy & Ho & $\mathrm{Er}$ & $\mathrm{Tm}$ & $\mathrm{Yb}$ & $\mathrm{Lu}$ & $\mathrm{Y}$ & $\begin{array}{c}\text { sum } R E E \\
+\mathrm{Y}\end{array}$ & $\begin{array}{l}\text { LREE/ } \\
\text { HREE }\end{array}$ & Method \\
\hline Pécsely (bulk 1) & 19.3 & 22.9 & 4.39 & 18.1 & 3.87 & 0.77 & 4.22 & 0.66 & 3.84 & 0.77 & 1.95 & 0.25 & 1.41 & 0.20 & 33.3 & 115.9 & 5.21 & ICP-MS \\
\hline Pécsely (bulk 2) & 27.0 & 27.7 & 5.09 & 20.7 & 4.29 & 0.86 & 5.02 & 0.81 & 5.05 & 1.15 & 3.23 & 0.44 & 2.67 & 0.40 & 53.2 & 157.6 & 4.56 & \\
\hline Tata (bulk) & 190 & 564 & 34.3 & 140 & 28.5 & 6.23 & 29.7 & 4.54 & 25.2 & 5.16 & 13.5 & 1.85 & 10.8 & 1.59 & 180 & 1235.4 & 10.43 & \\
\hline Pécsely-1 & 26.62 & 32.39 & 7.17 & 36.39 & 7.59 & 1.91 & 10.7 & 1.27 & 8.71 & 1.54 & 3.16 & 0.49 & 2.13 & 0.34 & 60.41 & 261.3 & 1.26 & LA-ICP- \\
\hline Pécsely-2 & 21.12 & 25.57 & 5.39 & 26.48 & 5.82 & 1.36 & 8.4 & 1.24 & 5.94 & 1.1 & 2.76 & 0.24 & 1.51 & 0.16 & 45.09 & 197.3 & 1.29 & MS \\
\hline Pécsely-3 & 13.34 & 16.63 & 3.06 & 15.15 & 3.13 & 0.44 & 3.1 & 0.63 & 4.23 & 0.61 & 1.58 & 0.09 & 0.58 & 0.14 & 28.16 & 119 & 1.32 & \\
\hline Pécsely-4 & 17.16 & 19.76 & 3.71 & 15.01 & 3.37 & 0.77 & 3 & 0.43 & 4.49 & 0.79 & 1.61 & 0.19 & 1.41 & 0.25 & 36.92 & 145.8 & 1.22 & \\
\hline Pécsely-5 & 27.08 & 31.86 & 6.93 & 38.03 & 8.18 & 1.99 & 9.7 & 1.08 & 7.78 & 1.79 & 3.98 & 0.32 & 1.41 & 0.21 & 60.73 & 261.8 & 1.31 & \\
\hline Pécsely-6 & 11.8 & 18.49 & 3.25 & 16.27 & 4.07 & 0.88 & 3.4 & 0.39 & 2.44 & 0.54 & 1.42 & 0.12 & 0.72 & 0.07 & 24.41 & 112.7 & 1.63 & \\
\hline Pécsely-7 & 15.63 & 20.9 & 4 & 20.19 & 4.2 & 0.87 & 4.3 & 0.65 & 3.35 & 0.57 & 1.6 & 0.22 & 0.65 & 0.18 & 31.91 & 141.1 & 1.51 & \\
\hline Tata-1 & 304.22 & 1024.12 & 44.2 & 204.07 & 38.1 & 10.62 & 42.5 & 6.08 & 36.37 & 7.23 & 18.37 & 2.44 & 13.71 & 2.24 & 266.57 & 2287.4 & 4.11 & \\
\hline Tata-2 & 324.33 & 1046.85 & 47.39 & 220.72 & 41.44 & 9.96 & 48 & 6.92 & 43.15 & 8.56 & 24.41 & 2.94 & 19.55 & 2.86 & 319.82 & 2486.7 & 3.55 & \\
\hline Tata-3 & 419.55 & 1164.28 & 62.63 & 283.63 & 51.29 & 13.64 & 65.7 & 8.67 & 49.91 & 10.82 & 28.62 & 3.07 & 19.9 & 2.57 & 384.67 & 2953.6 & 3.48 & \\
\hline Tata-4 & 342.01 & 971.72 & 51.44 & 226.74 & 41.82 & 11.24 & 46.9 & 7.24 & 43.82 & 8.57 & 20.58 & 2.33 & 16.39 & 2.4 & 322 & 2437.2 & 3.5 & \\
\hline Tata-5 & 97.03 & 308.52 & 12.25 & 57.01 & 10.28 & 3.15 & 12.1 & 1.95 & 11.92 & 2.66 & 8.52 & 1.72 & 9.66 & 1.63 & 104.85 & 748.1 & 3.15 & \\
\hline Tata-6 & 273.03 & 1025.72 & 45.75 & 202.19 & 38.37 & 9.33 & 46.6 & 6.1 & 34.98 & 7.36 & 17.42 & 2.04 & 14.02 & 2.08 & 267.13 & 2259.3 & 4.01 & \\
\hline Tata-7 & 147.94 & 551.98 & 23.12 & 101.06 & 21.5 & 5.16 & 19.6 & 3.01 & 18.04 & 3.38 & 9.53 & 1.32 & 6.84 & 0.95 & 129.66 & 1172.7 & 4.42 & \\
\hline Tata-8 & 114.64 & 468.21 & 18.37 & 78.36 & 15.13 & 3.9 & 19.9 & 3.05 & 14.75 & 2.89 & 7.49 & 0.88 & 5.79 & 0.85 & 104.6 & 963.4 & 4.36 & \\
\hline Tata-9 & 304.85 & 939.28 & 46.14 & 196.92 & 40.13 & 9.97 & 43.8 & 5.56 & 35.76 & 7.66 & 18.04 & 2.36 & 12.85 & 1.88 & 279.31 & 2223.8 & 3.78 & \\
\hline NASC* & 31.1 & 67.03 & 9.1 & 30.4 & 5.98 & 1.25 & 5.5 & 0.85 & 5.54 & 1.27 & 3.28 & 0.54 & 3.11 & 0.46 & $27^{* *}$ & & & \\
\hline Sample & Th & $\mathrm{U}$ & V & $\mathrm{Cr}$ & $\mathrm{Sc}$ & $\mathrm{Ni}$ & $\mathrm{Co}$ & $\mathrm{Ce} / \mathrm{Ce} *$ & $\mathrm{Eu} / \mathrm{Eu}^{*}$ & $\operatorname{Pr} / \operatorname{Pr} *$ & $\mathrm{La} / \mathrm{Yb}$ & $\mathrm{La}_{\mathrm{N}} / \mathrm{Sm}_{\mathrm{N}}$ & v/Ho & $\mathrm{Th} / \mathrm{U}$ & $\mathrm{Th} / \mathrm{V}$ & $\mathrm{V} / \mathrm{Cr}$ & $\mathrm{V} / \mathrm{Sc}$ & $\mathrm{Ni} / \mathrm{Co}$ \\
\hline & & 137.69 & & 23.88 & 3.93 & 15.45 & 0.27 & & & & & & 39.27 & 0.04 & & & & \\
\hline Pécsely-2 & 1.88 & 257.99 & 480.59 & 13.13 & 2.17 & 6.28 & 0.21 & 0.6 & 1.03 & 0.53 & 1.40 & 0.70 & 41.15 & 0.01 & 0.00 & 36.61 & 221.58 & 30.56 \\
\hline Pécsely-3 & 0.60 & 525.32 & 765.75 & 23.05 & 1.68 & 0.82 & 0.49 & 0.65 & 0.46 & 0.39 & 2.31 & 0.82 & 46.22 & 0.001 & 0.00 & 33.21 & 455.88 & 1.67 \\
\hline Pécsely-4 & 0.53 & 549.97 & 749.12 & 20.22 & 1.16 & 1.07 & 0.51 & 0.62 & 0.83 & 0.46 & 1.22 & 0.98 & 46.89 & 0.001 & 0.00 & 37.05 & 643.42 & 2.12 \\
\hline Pécsely-5 & 1.31 & 310.60 & 340.47 & 28.67 & 1.91 & 11.35 & 0.34 & 0.58 & 1.38 & 0.58 & 1.92 & 0.64 & 33.89 & 0.004 & 0.00 & 11.88 & 178.13 & 33.53 \\
\hline Pécsely-6 & 0.28 & 262.19 & 200.26 & 20.79 & 1.29 & 11.08 & 0.90 & 0.75 & 0.91 & 0.40 & 1.63 & 0.56 & 45.19 & 0.001 & 0.00 & 9.63 & 155.44 & 12.25 \\
\hline Pécsely-7 & 0.41 & 612.1 & 810.70 & 35.81 & 1.30 & 8.47 & 0.72 & 0.66 & 0.82 & 0.45 & 2.40 & 0.72 & 55.68 & 0.001 & 0.00 & 22.64 & 622.5 & 11.82 \\
\hline Tata-1 & 23.57 & 14.99 & 327.57 & 19.05 & 6.10 & 562.51 & 48.04 & 2.22 & 3.30 & 1.04 & 2.22 & 1.54 & 36.88 & 1.57 & 0.07 & 17.19 & 53.7 & 11.71 \\
\hline Tata-2 & 30.09 & 17.39 & 481.98 & 34.32 & 8.65 & 953.16 & 79.82 & 2.12 & 2.95 & 1.09 & 1.66 & 1.50 & 37.37 & 1.73 & 0.06 & 14.04 & 55.73 & 11.94 \\
\hline Tata-3 & 27.18 & 26.11 & 153.36 & 513.08 & 4.56 & 245.17 & 23.03 & 1.80 & 3.62 & 1.33 & 2.11 & 1.57 & 35.55 & 1.04 & 0.18 & 11.73 & 33.6 & 10.65 \\
\hline Tata-4 & 24.10 & 21.63 & 169.58 & 242.93 & 5.43 & 258.17 & 24.96 & 1.84 & 3.29 & 1.21 & 2.09 & 1.57 & 37.56 & 1.11 & 0.14 & 0.70 & 31.23 & 10.34 \\
\hline
\end{tabular}



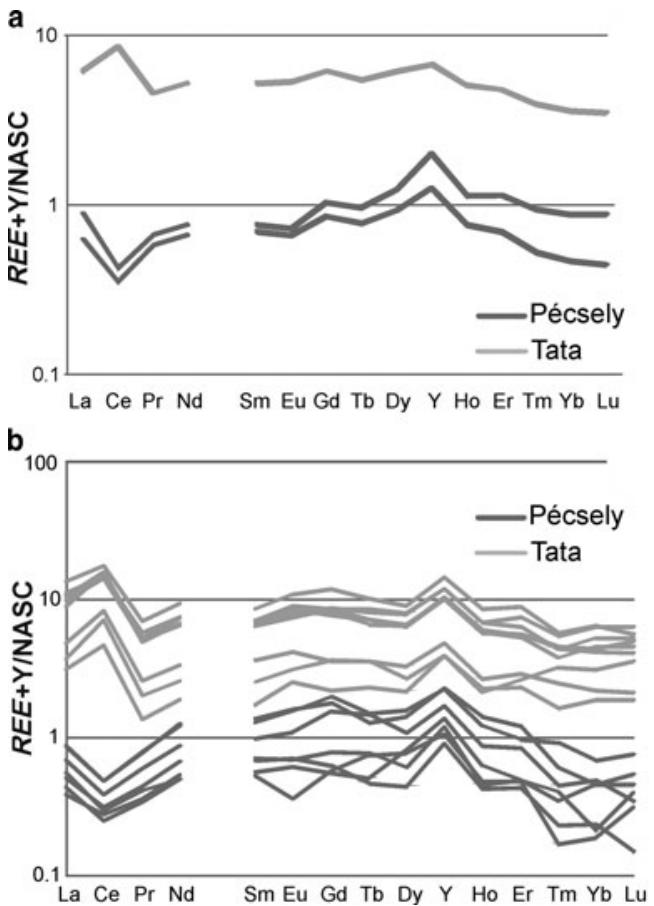

Fig. 10. (a) Bulk-rock NASC-normalized REE distribution diagram of phosphorite (ICP-MS). The phosphorite from Pécsely is slightly depleted in relation to the NASC and indicates negative $\mathrm{Ce}$ and $\mathrm{Eu}$ anomalies, while the phosphorite from Tata is enriched in relation to the NASC and shows positive $\mathrm{Ce}$ and $\mathrm{Eu}$ anomalies. (b) NASCnormalized $R E E+\mathrm{Y}$ distribution diagram of the individual CFA minerals (LA-ICP-MS). Similar to the results of the bulk analyses, the Triassic phosphorite is slightly depleted relative to the NASC and shows negative $\mathrm{Ce}$ and $\mathrm{Eu}$ anomalies. Phosphorite from Tata is enriched relative to the NASC and shows positive $\mathrm{Ce}$ and Eu anomalies.

are $R_{\mathrm{Th}-\mathrm{U}}^{2}=-0.71$ and $R_{\mathrm{Th}-\mathrm{V}}^{2}=-0.48$ in the case of Pécsely and $R_{\mathrm{Th}-\mathrm{U}}^{2}=0.83$ and $R_{\mathrm{Th}-\mathrm{V}}^{2}=-0.54$ in the case of Tata (Fig. 11a,b).

The $\mathrm{Ce} / \mathrm{Ce}^{*}$ values vary between 0.59 and 0.75 , the $\mathrm{Eu} / \mathrm{Eu}^{*}$ ratios range from 0.46 to 1.38 and $\mathrm{Pr} /$ Pr* ranges from 0.39 to 0.61 in the phosphorite from Pécsely. As in the phosphorite nodules from Tata, $\mathrm{Ce} / \mathrm{Ce}^{*}$ values vary between 1.8 and $2.56, \mathrm{Eu} /$ Eu* values vary between 1.83 and 3.62 , and $\delta \operatorname{Pr} \operatorname{Pr} /$ Pr* from 0.53 to 1.33 (Table 2). $\mathrm{La}_{\mathrm{N}} / \mathrm{Sm}_{\mathrm{N}}$ values are from 0.56 to 0.98 and $\mathrm{Y} / \mathrm{Ho}$ values vary between 34 and 56 in Triassic phosphorite and $\mathrm{La}_{\mathrm{N}} /$ $\mathrm{Sm}_{\mathrm{N}}$ values are from 1.32 to 1.81 and $\mathrm{Y} / \mathrm{Ho}$ values vary between 35.5 and 39.4 in Cretaceous phosphorite (Table 2). 
TABLE 3. Diagnostic element ratios indicating redox conditions for the depositional environment of phosphorite.

\begin{tabular}{lcccc}
\hline Indicator & Oxic & Suboxic & Anoxic & Euxinic \\
\hline $\mathrm{H}_{2} \mathrm{~S}$ & \multicolumn{2}{c}{ No free $\mathrm{H}_{2} \mathrm{~S}$ in the water column } & Free $\mathrm{H}_{2} \mathrm{~S}$ present in the water column \\
\hline $\mathrm{O}_{2}$ concentration in bottom $^{\text {waters }}{ }^{\mathrm{a}}\left(\mathrm{mLO}_{2} / \mathrm{LH}_{2} \mathrm{O}\right)$ & $\mathrm{O}_{2}>2$ & $0.2<\mathrm{O}_{2}<2$ & $\mathrm{O}_{2}<0.2$ & $\mathrm{O}_{2}=0$ \\
$\mathrm{Th}^{\mathrm{C}} \mathrm{U}^{\mathrm{b}}$ & $>7$ & $2-7$ & $0-2$ & - \\
$\mathrm{V} / \mathrm{Cr}^{\mathrm{c}}$ & $<2$ & $2-2.45$ & $>4.25$ & $>4.25$ \\
$\mathrm{Ni} / \mathrm{Co}^{\mathrm{c}}$ & $<5$ & $5-7$ & $>7$ & - \\
$\mathrm{V} / \mathrm{Sc}^{\mathrm{d}}$ & - & - & - & $>24$ \\
& & & & \\
\hline
\end{tabular}

${ }^{\mathrm{a}}$ Tyson and Pearson (1991).

${ }^{\mathrm{b}}$ Wignall and Twichett (1996). ${ }^{\mathrm{c} J o n e s}$ and Manning (1994).

${ }^{\mathrm{d}}$ Kimura and Watanabe (2001).

The carbon and oxygen isotopic compositions of calcite crystals found in the layered Triassic phosphorite unit as well as in the host-rock limestone are listed in Table 4. The measurements were performed on calcite in different textural elements like host-rock limestone, hairline fractures in phosphorite, hematitized host limestone and calcite cement of the brecciated phosphorite and the results were compared to the typical seawater values (Fig. 12). The stable isotope composition of the host limestone $\left(\delta^{18} \mathrm{O}_{\text {carbPBD }}=\right.$ from -2.18 to $-1.54 ; \delta^{13} \mathrm{C}_{\text {carbPBD }}=$ from 1.86 to 1.99 ) shows the typical Middle Triassic seawater stable isotope data $\left(\delta^{18} \mathrm{O}_{\text {carbPBD }}=\right.$ from -2.18 to $-1.54 ; \delta^{13} \mathrm{C}_{\text {carbPBD }}=$
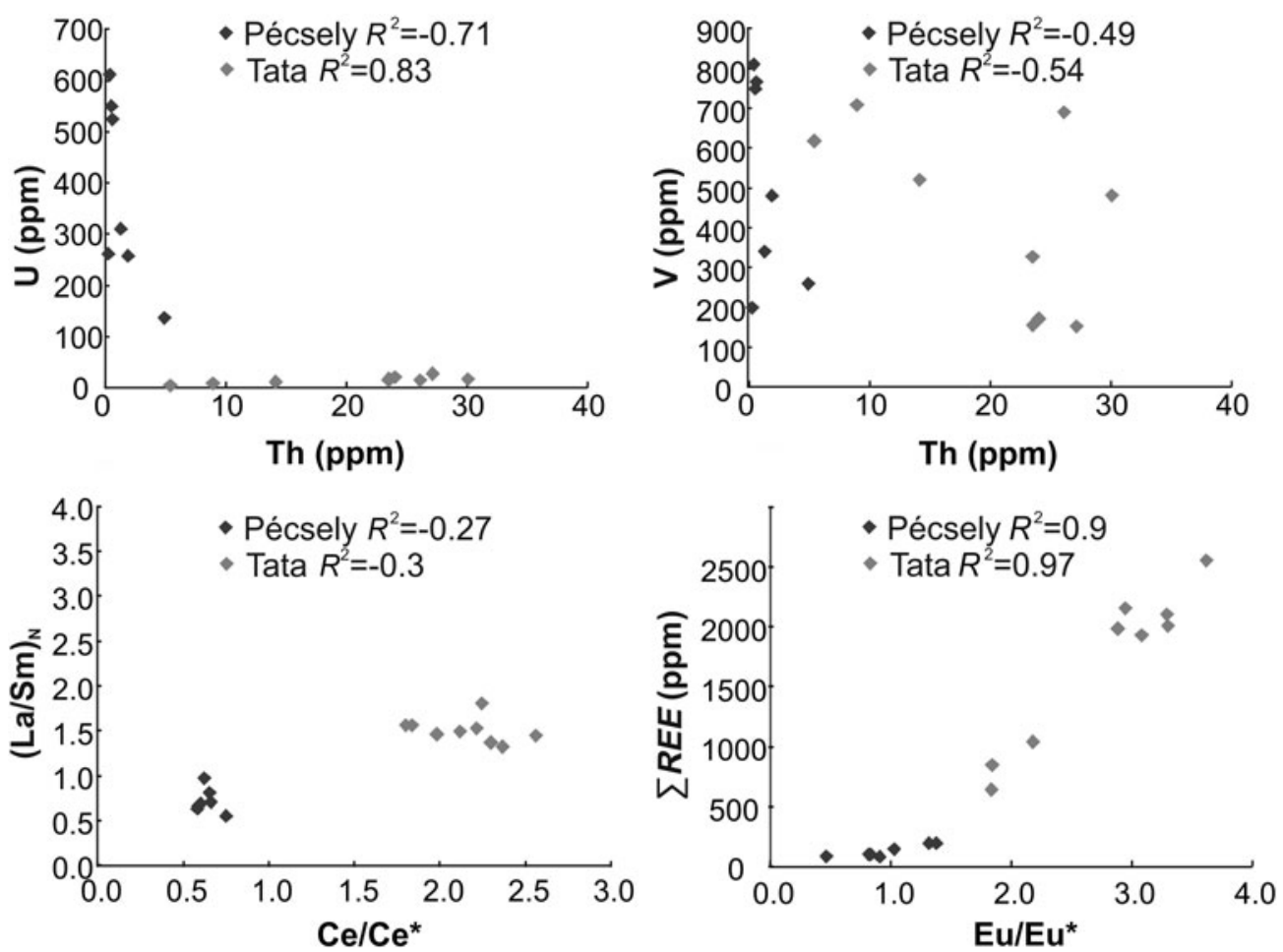

FIG. 11. Cross-plots of various parameters based on the LA-ICP-MS analyses of Triassic and Cretaceous phosphorite horizons. 
TABLE 4. Stable isotope data of calcite found in different textural positions in the Triassic phosphorite horizon.

\begin{tabular}{lccccr}
\hline Sample description & $\delta^{18} \mathrm{O}_{\mathrm{PDB}}$ & $\delta^{13} \mathrm{C}_{\mathrm{PDB}}$ & Sample description & $\delta^{18} \mathrm{O}_{\mathrm{PDB}}$ & $\delta^{13} \mathrm{C}_{\mathrm{PDB}}$ \\
\hline 1 & -1.54 & 1.94 & 3 & -7.96 & -1.07 \\
1 & -1.60 & 1.99 & 3 & -7.97 & -1.14 \\
1 & -1.97 & 1.99 & 3 & -8.02 & -1.29 \\
1 & -2.00 & 1.96 & 3 & -7.93 & -1.50 \\
1 & -2.18 & 1.86 & Average & -7.95 & -0.34 \\
1 & -2.16 & 1.91 & 4 & -7.97 & -0.11 \\
Average & -1.91 & 1.94 & 4 & -7.52 & 0.01 \\
2 & -6.42 & -2.75 & 4 & -7.54 & -1.16 \\
2 & -6.55 & -2.89 & 4 & -7.47 & -1.16 \\
2 & -7.30 & -4.75 & 4 & -8.12 & -1.36 \\
2 & -7.28 & -4.73 & 4 & -8.06 & -1.30 \\
2 & -7.63 & -5.50 & 4 & -7.79 & -0.92 \\
2 & -7.63 & -5.50 & 4 & -7.99 & -0.60 \\
Average & -7.13 & -4.35 & 4 & -7.34 & -2.29 \\
3 & -7.96 & 1.55 & 4 & -7.38 & -1.50 \\
3 & -7.86 & 1.38 & Average & -7.72 & -1.04 \\
\hline
\end{tabular}

1: Host rock limestone (syngenetic with phosphorite).

2: Hematitized limestone.

3: Calcite cement of brecciated phosphorite.

4: Hairline fracture-filling calcite.

from 1.86 to 1.99 ; Korte et al., 2005), while the other three groups are well separated from that, plotting out of the field of Middle Triassic seawater.

\section{Discussion}

The structure, texture, mineral compositions and whole-rock chemistry of the Cretaceous and

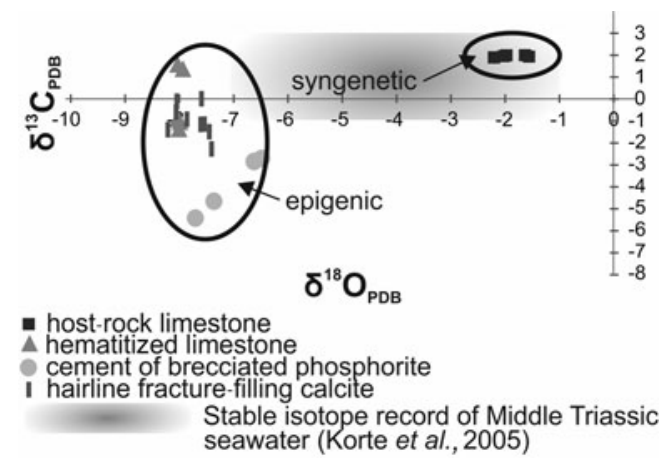

FIG. 12. Carbon and oxygen isotope data of the calcite from the Triassic phosphorite. The negative shift of $\delta^{18} \mathrm{O}$ values (relative to original marine values) found in epigenic calcite can be explained by fluid-rock interaction during a hydrothermal process (Meneghini et al., 2012; Choi et al., 2003).
Triassic phosphorites show significant differences which reflect corresponding differences in their genesis. The Triassic phosphorite is laminar whilst the Cretaceous phosphorite is nodular although groups of nodules are surrounded by a laminar crust. Carbonate-bearing fluorapatite (CFA) is the main phosphorous-bearing mineral in both phosphorites but the Triassic phosphorite is characterized by a higher $\mathrm{U}$ and a lower $R E E$ content, whilst the Cretaceous occurrence has a lower $U$ and a higher REE content.

\section{Sedimentary phosphogenesis}

At the genesis of large-scale phosphorite deposits, two major requirements have to be fulfilled. Firstly, phosphorous must be concentrated at levels from 1 to 2 million times above that of average seawater. Secondly, the phosphate should be accumulated in a stable, crystalline mineral phase (e.g. CFA; Knudsen and Gunter, 2002). Phosphate enrichment in sediments is accomplished in three ways (Föllmi, 1996 and references therein, Pufahl and Groat, 2017). Microbial breakdown of organic matter and release of organic phosphate to pore waters represent the most fundamental internal source of phosphate. A second and potentially important 
process supplying dissolved phosphate to interstitial fluids is phosphate desorption from iron and manganese oxyhydroxides upon burial or biologically induced advection below the redox boundary in sediments and subsequent reduction. A third and less well explored source of dissolved phosphate is when it precipitates directly at the sediment-water interface or is transferred into the sediments by diffusion.

Marine phosphorites are distinguished according to their tectonic and oceanographic setting: epicontinental sea phosphorites, continental margin phosphorites, seamount phosphorites and insular phosphorites (Fig. 13; Glenn et al., 1994).

According to their appearance, three types of phosphorites can be distinguished. (1) Phosphate nodules with spherical concentrations that are randomly distributed on the floor of continental shelves. Most phosphorite grains are sand-sized, although particles greater than $2 \mathrm{~mm}$ may be also present. These larger grains, referred to as nodules, can range up to several tens of $\mathrm{cm}$ in size. (2) Bioclastic phosphates or bone beds are bedded phosphate deposits that contain concentrations of small skeletal particles and coprolites. Some of these also contain invertebrate fossils such as brachiopods and the deposits become more enriched in $\mathrm{P}_{2} \mathrm{O}_{5}$ after diagenesis. Bioclastic phosphates can also be cemented by phosphate minerals. (3) Phosphatization is a diagenetic process that occurs during leaching of guano which creates phosphate-rich fluids that are then concentrated and re-precipitated in limestone. Phosphatized fossils or fragments of original phosphatic shells are important components of some of these deposits (Baturin, 1982).

Based on the geological settings and the deposition types presented above, we deduce that the phosphorite horizons from Pécsely are typical seamount phosphorites, where the lowermost layers can be interpreted as a hardground. Based on the rich fossil content of the sequence, the source of phosphate comes from the microbial breakdown of organic matter and release of organic phosphate to pore waters. This is a bedded phosphate deposit which contains bioclasts and small skeletal particles. The $\mathrm{U}$ content of these layers is greater than the typical value of this deposit type (Baturin and Kochenov, 2001). In contrast, the phosphorite from Tata is an upwelling-related occurrence, which formed on the margin of a distal shelf. The microbial degradation of accumulating sedimentary organic matter produces an oxygen minimum zone and stimulates phosphogenesis. The phosphate fabrics are microbial-mat-derived, where microbial mats act as a sediment binder or as substrate for apatite precipitation (Pufahl and Groat, 2017). Similarly to other upwelling-related occurrences, this formation is enriched in REEs.

In the following, the conditions of formation of the two deposits and their economic potential as sources of critical elements are discussed.

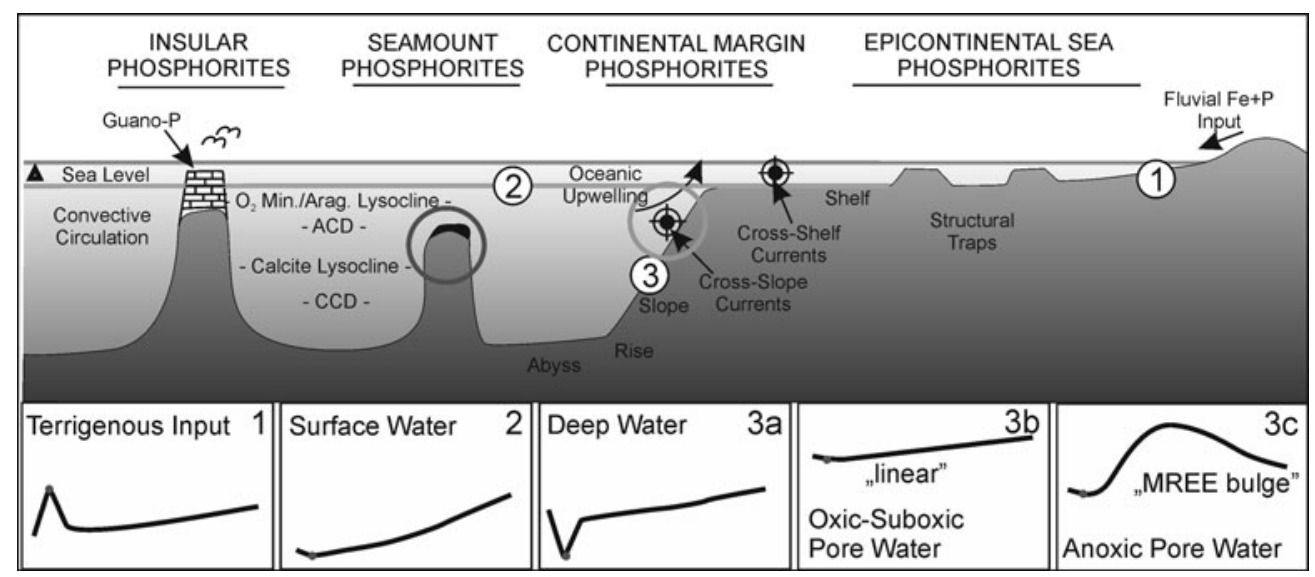

FIG. 13. Schematic sketch depicting the different phosphorite depositional environments and assumed REE patterns (13c) (Glenn et al., 1994; Shields and Stille, 2001). Transgression resulted in drowning of the platform, reworking of microbial mats and phosphatic sediments. The dark circle shows the possible formation environment of the phosphorite studied from Pécsely, while the light-coloured circle shows that from Tata. The shape of the NASC-normalized REE patterns shows the 'MREE bulge' (3c), which also confirms the anoxic depositional environment. 


\section{Redox-sensitive element geochemistry}

\section{Evaluation of detrital input}

The oxygen level in the water can control the degree of enrichment of elements in marine sediments (Wignall and Twitchett, 1996). Redox-sensitive proxies, such as $\mathrm{Th} / \mathrm{U}, \mathrm{V} / \mathrm{Sc}$ ratios and $R E E$ concentrations can reflect regional or global redox conditions and be used as palaeo-oceanic redox environment proxies (Morford and Emerson, 1999).

Detrital, biogenic and hydrogenous fractions show three independent concentrations of sediments (Piper, 1994). Monitoring the detrital fraction is necessary to assess the enrichment of redox-sensitive elements relative to their detrital component. The Th content is largely independent of the source area or the grain size (Taylor and McLennan, 1985) and it is used here to monitor the detrital input. The lack of correlation between Th and $\mathrm{U}$ or $\mathrm{V}$, and the $\mathrm{Y} / \mathrm{Ho}$ ratios suggests that there has been no detrital influence on redox-sensitive elements and REE patterns at Pécsely (Fig. 11a,b). However, the correlation coefficient between Th and $\mathrm{U}$ (Fig. 11a) suggests that a detrital influence at Tata cannot be excluded. The siliciclastic material at the hiatus and within the nodular phosphorite may come from the Hautevirian-Albian Lábatlan Sandstone Formation.

\section{Redox conditions}

In oxic seawater, uranium is present mainly as $\mathrm{U}$ (VI) uranyl ions, which bind to carbonate ions (Langmuir, 1978). In reducing marine settings, U (VI) can be reduced to U(IV) (Wignall and Twitchett, 1996). Thorium is stable in the seawater and occurs permanently in the insoluble Th(IV) state (Tribovillard et al., 2006). Vanadium, as a redox-sensitive element, is enriched preferentially in sediments underlying anoxic or near anoxic waters. The degree of enrichment is expressed as the $\mathrm{V} / \mathrm{Sc}$ ratio, because the reduced forms of $\mathrm{V}$ and $\mathrm{Sc}$ are equally insoluble, whereas the abundance of $\mathrm{V}$ in shales varies with Sc (Kimura and Watanabe, 2001). Significant V enrichment over Sc is most likely to be related to deposition beneath anoxic bottom waters (Kimura and Watanabe, 2001). Another approach proposed by Jones and Manning (1994) for determining the depositional environment is the observation of $\mathrm{V} / \mathrm{Cr}$ and $\mathrm{Ni} / \mathrm{Co}$ ratios. The ranges of these ratios appropriate to the different environments are shown in Table 2.

In the Triassic samples from Pécsely, $\mathrm{Th} / \mathrm{U}$ ratios ranging from 0.001 to 0.036 (Table 1) indicate the precipitation of phosphorite in reductive (anoxicsuboxic) conditions. The $\mathrm{V} / \mathrm{Sc}$ ratios (from 66 to 643) also indicate anoxic-euxinic sedimentary conditions. The $\mathrm{V} / \mathrm{Cr}$ ratios range from 9 to 37 , and these results suggest anoxic sedimentary conditions, where free $\mathrm{H}_{2} \mathrm{~S}$ was present in the water column. $\mathrm{Ni} / \mathrm{Co}$ ratios were $\sim 7$ in these phosphorite layers and this ratio is considered to indicate anoxic water conditions. This condition existed when the phosphorite was formed, but the rich ammonite fauna and other fossils appearing in the strata indicate that oxic conditions were typical among the formation of the three phosphorite horizons.

In the Cretaceous samples from Tata, $\mathrm{Th} / \mathrm{U}$ ratios (from 0.96 to 1.74 , Table 1) indicate reducing sedimentary conditions. The $\mathrm{V} / \mathrm{Sc}$ ratios (from 31 to 112), indicate that this nodular phosphorite formed in an anoxic-euxinic sedimentary environment, where free $\mathrm{H}_{2} \mathrm{~S}$ was present in the water column. The $\mathrm{V} / \mathrm{Cr}$ ratios range from 0.7 to 25 which are inconclusive with regard to the formation environment. The $\mathrm{Ni} / \mathrm{Co}$ ratios show that this phosphorite formed in an anoxic environment close to the boundary with suboxic conditions.

Taken together the $\mathrm{Th} / \mathrm{U}, \mathrm{V} / \mathrm{Sc}, \mathrm{V} / \mathrm{Cr}$, and $\mathrm{Ni} / \mathrm{Co}$ ratios indicate that the phosphorites from both areas formed under anoxic conditions.

\section{REE distribution patterns: the behaviour of $\mathrm{Ce} /$ $\mathrm{Ce}^{*}, \mathrm{Eu} / \mathrm{Eu}^{*}$ and $\mathrm{Y}$}

McArthur and Walsh (1984) suggested that Ce anomalies can be changed during later diagenesis. However, if no correlation is observed between $\mathrm{Ce}$ anomalies and $\mathrm{La}_{\mathrm{N}} / \mathrm{Sm}_{\mathrm{N}}\left(\mathrm{La}_{\mathrm{N}} / \mathrm{Sm}_{\mathrm{N}}\right.$ ratios $\left.>0.35\right)$ (Fig. 11c) or the $\mathrm{Eu} / \mathrm{Eu}^{*}$ and REE contents (Fig. 11d) then Ce anomalies in phosphorite may represent primary signatures (Morad and Felitsyn, 2001). Before using the negative Ce-anomaly data, the influence of positive $\mathrm{La}$ anomalies must be removed, which can be examined using $\mathrm{Pr} / \mathrm{Pr}$ * values (Bau, 1999). According to Bau and Koschinsky (2009), if the samples present $\mathrm{Pr} / \mathrm{Pr}$ * > 1.05 , the negative Ce anomaly is real; in contrast, a positive La anomaly may lead to overestimation. At both Pécsely and Tata no correlation was observed between $\mathrm{Ce}$ anomalies and $\mathrm{La}_{\mathrm{N}} / \mathrm{Sm}_{\mathrm{N}}$ $\left(\mathrm{La}_{\mathrm{N}} / \mathrm{Sm}_{\mathrm{N}}\right.$ ratios $\left.>0.35\right)$ (Fig. 11c) $\left(R_{\text {Pécsely }}^{2}=-0.27\right.$ $\left.R_{\text {Tata }}^{2}=-0.31\right)$, but the $\mathrm{Eu} / \mathrm{Eu}^{*}$ and $R E E$ contents show strong correlation $\left(R_{\text {Pécsely }}^{2}=0.9, R_{\text {Tata }}^{2}=0.97\right)$, which suggests that diagenetic change in the $\mathrm{Ce}$ anomaly is substantial. 
Positive Eu anomalies in marine environments are common if hydrothermal fluids have been present in the system (Michard, 1989). At Pécsely, the $\mathrm{Eu} / \mathrm{Eu}^{*}$ ratios range from 0.46 to 1.38 , while at Tata they range from 1.83 to 3.62 . Thus, Pécsely shows changeable, slightly negative or slightly positive anomalies while Tata has distinct positive anomalies (Fig. 10b). Therefore, the relatively high $\mathrm{Eu} / \mathrm{Eu}^{*}$ ratios of the phosphorite from Tata may be due to hydrothermal fluid input. The variable Eu/ $\mathrm{Eu}^{*}$ signatures of the Pécsely phosphorite may reflect gradual weakening of the hydrothermal activity due to the Triassic volcanism (Pálfy et al., 2003).

Ytterbium is trivalent and possesses chemical properties similar to those of the REE. This element is considered to be a geochemical twin to Ho, because these two elements have identical ionic radii and valences (Bau, 1996). Whereas the continental crust, mantle and high-temperature hydrothermal fluids are characterized by chondritic Y/Ho ratios $(\sim 26)$, seawater has super-chondritic Y/Ho ratios ( 47) (Bau, 1996; Nozaki et al., 1997). Y/Ho ratio variability between seawater and the other media is due to higher particle-reactivity of Ho, which is scavenged preferentially over $\mathrm{Y}$ by hydrogenous ferromanganese oxyhydroxide particles in the marine environment (Bau, 1996, 1999; Koschinsky et al., 1997). The Y/Ho ratio of CFA from Pécsely shows a variation from 33.9 to 55.7, while the CFA from Tata is characterized by relatively constant values, ranging from 35.5 to 39.4. Both Y/Ho ranges are consistent with the positive $\mathrm{Y}$ anomalies (0.9 to 2.25 ). Although it is unlikely that marine conditions were identical to those in the modern Pacific Ocean, the mostly super-chondritic $\mathrm{Y} / \mathrm{Ho}$ ratios and positive $\mathrm{Y}$ anomalies suggest a predominant seawater source for apatite from Pécsely and the lower Y/Ho values may indicate some hydrothermal input. The low Y/ Ho ratios and positive $Y$ anomalies (3.9 to 14.2) suggest clearly a mixed origin for the CFA from Tata and could also indicate the involvement of a hydrothermal fluid, although there is no known geological evidence for this.

\section{The possible sources of $P, U$ and REE in phosphorites}

The phosphorous in the oceans may come from: (1) deep-water dissolved phosphate; (2) fluvialdissolved phosphate from rock weathering; (3) volcanic emanations; (4) interstitial water reflux from sediments; and (5) regeneration via organic carbon oxidation in the water column (Arthur and Jenkyns, 1981).

Several factors may influence the concentration and pattern of $R E E$ distribution in phosphorites. These include physicochemical conditions of phosphorite formation, the presence of a biogenic component in the phosphogenic system, contact duration with seawater, post-deposition alterations, diagenetic modifications and texture of phosphate components (Wright et al., 1984; Shields and Stille, 2001; Zanin and Zamirailova, 2009).

\section{The source of $P, U$ and REE in the layered phosphorite of Pécsely}

On the basis of the geological background and the latest sedimentological results, there were two possible sources for phosphorous on the platform. The indirect source of phosphorous could be the volcanic tuff layers of the Vászoly Limestone Formation. The estimated range of volcanic activity is $241.1-238 \mathrm{Ma}$ (Pálfy et al., 2003). The K-rich, trachitic, rapidly weathered volcanic ash probably increased the nutrient content of seawater, which led to a bloom in terms of marine organisms. This bloom was followed by degradation, leading to the emergence of a local anoxic or euxinic environment. The low oxygen level could result in the release of phosphorous to form synsedimentary phosphorite, which is in good agreement with the age data. The other possible source is the monsoonderived upwelling model (De Wever et al., 2014), as Budai et al. (2017) have used to describe this area. According to that model, the high fertility of the surface water (supported by an extraordinary diverse ammonite fauna) was related to monsoonderived up-welling, where the coeval volcanic tuff input might have contributed to the fertilization. As the area studied is a small isolated platform and the phosphorite occurs just at the NE part, a local control is suggested, such as the effect of winddriven currents along the windward margin of the submarine high (Budai et al., 2017). Based on the present study, all these models of phosphorite formation are possible.

There are two possible sources of the $\mathrm{U}$ and $R E E$ content. The first is the tuffs of the K-trachyte volcanism which are present in the area (Cros and Szabó, 1984). As the tuff is strongly altered, the trace elements of the rock-forming minerals could have been released and precipitated with the phosphorites. This idea is supported by the fact that the tuff also contains REE-bearing xenotime. 
The other source might be the fluvial Permian red sandstone, which is found extensively at the Balaton Highland. The reduced layers of this sandstone contain U-bearing minerals (Budai et al., 1999). The extensional tectonic event, which formed half graben-type hemipelagic basins and isolated carbonate platforms in the area of TDMR during the Pelsonian, resulted in deep normal faults (Budai and Vörös, 1992, 2006; Budai et al., 1999; Haas and Budai, 1995; Vörös et al., 1997; Pálfy et al., 2003; Budai and Vörös, 2006). These faults reached the Permian red sandstone. Fluids could have ascended along these faults, partly dolomitizing the lower Triassic limestone and establishing some base metal ore indications along the boundary of organic-matterrich horizons (Györi et al., 2014). It is possible, therefore, that the dissolved U was derived from the early diagenesis stage of the Permian red sandstone.

The geochemical analyses suggest that the simultaneous volcanic activity had a subordinate role, based on the subordinate contribution of the hydrothermal activity detected. However, a small contribution of an epigenetic hydrothermal fluid was indicated and supported also by the stable isotope data of calcite appearing epigenetically with the phosphorite (Fig. 13). Therefore, the $\mathrm{U}$ (and $R E E$ ) content of the Permian red sandstone seems most likely to have been mobilized by hydrothermal fluids along the above-mentioned faults.

\section{The source of $P, U$ and REE in the nodular phosphorite of Tata}

It is more difficult to determine the origin of $U$ and the REE in the Tata phosphorite because the layers appear in a sedimentation gap representing $\sim 30$ m.y. (Fülöp, 1954).

The geochemical study showed clearly that the $R E E$ content of the phosphorite nodule from Tata is greater than that of the North Atlantic Shale composite (Gromet et al., 1984). The correlation coefficient between $T h$ and $U$ indicates that the detrital influence could be a possible cause of high $R E E$ content of the phosphorite. The relatively high positive Eu anomaly of Tata presents hydrothermal fluid input in a marine environment (Michard, 1989), although this Eu anomaly may have other origins also.

The phosphorite nodules are found at the base of the Cretaceous layers, so they formed during the Selli Event (OAE 1a) ( 120 Ma) and/or the Paquier Episode (OAE 1b) (Föllmi, 2012). Oceanic Anoxic Events (OAE) correlate with particularly high sea levels, although these do not generally coincide with major phosphorogenic episodes (Föllmi, 2012). This may be due to the fact that during OAEs, abundant phosphorous is fixed in the deep sea with well preserved organic carbon and is hence unavailable to form on a shallow shelf in competition with other sites of phosphate fixation. However, phosphatized seamount limestone and phosphatic hardgrounds in a shelf carbonate sequence may be formed during OAEs (Arthur and Jenkyns, 1981). However, in the area investigated, the number of discordant surfaces as well as the sedimentary-gap formation events which affected the area have not been determined yet. Although no previous research was performed on this topic, the results of the present study suggest that the most probable source of phosphorous at Tata is the deep-water dissolved phosphate.

Research by Larson and Erba (1999) has proven that 'super plume' events can play a significant role in OAE formation and can also increase the dissolved-metal content of the seawater. Larson (1991) calculated a $50-75 \%$ increase in oceanic crust formation rates from $120-80 \mathrm{Ma}$ that he associated with the formation of a 'super plume', when significant plate-margin volcanism evolved. The Ontong Java Plateau was formed at 125$120 \mathrm{Ma}$ ( Selli Event) and the Kerguelen Plateau at 119-110 Ma (Paquier Episode; Rampino and Stothers, 1988; Baksi, 1990). These and other traps correlate to the time span of the early Aptian to the early Albian.

We assume that the nodular phosphorite found in the studied hiatus of the Kálvária Hill formed during the Selli Event ( 120 Ma) and/or Paquier Episode $(\sim 110 \mathrm{Ma})$. The Selli Event is supported roughly by the age of the Ontong Java Plateau, the appearance of the laminated, organic-rich layers in the Tethys Basin and by the increase in sediment input by submarine slope debris (Lábatlan Sandstone Formation). Although intermittent anaerobic conditions are known from the Aptian/ Albian boundary interval and in the central Tethyan Basin, some possible correlations with organic-rich levels have been identified, notably the 'Urbino' level (an equivalent of the Paquier level) identified in the Ionian Zone of northwest Greece (Coccioni et al., 2006; Tsikos et al., 2004).

\section{Models of phosphorite formation}

Phosphorites can form under a number of tectonic and oceanographic settings. The Pécsely 
phosphorite formed on a small, isolated, submerged carbonate platform with an extraordinarily diverse ammonite fauna. This phosphorite formed during submergence bathing of the Tagyon Platform in oxygen-minimum zone waters or in a locally anoxic environment. The effects of diagenetic changes are shown as well as the lack of detrital input (Fig. 13). The phosphorite layers were formed with microbial mediation from the dissolved phosphate of seawater, induced partly by the nearby volcanic activity and the effects of a monsoon-derived upwelling (Budai et al., 2017). The mostly super-chondritic $\mathrm{Y} / \mathrm{Ho}$ ratios and positive $\mathrm{Y}$ anomalies suggest a predominant seawater source for apatite formation and the lower Y/Ho values may indicate some hydrothermal input (Bau, 1996) that may be connected to the gradual weakening of the hydrothermal activity related to the Triassic volcanism (Pálfy et al., 2003) or to the hydrothermal fluids derived along normal faults (Györi et al., 2014). This is supported by the stable isotope data (Fig. 12), as $\delta^{13} \mathrm{C}$ and $\delta^{18} \mathrm{O}$ values of the host carbonate, the cogenetic and the epigenetic calcite, show a pattern typical of the evolution of a hydrothermal system, where the limestone reacts with an isotopically different fluid (Meneghini et al., 2012; Choi et al., 2003).

The nodular phosphorite from Tata formed in anoxic (close to suboxic) bottom water, under reductive sedimentary conditions. Phosphogenesis took place in suboxic sediments in the vicinity of the sediment-water interface. The encrusting organisms have developed a typical microstratigraphy which is characterized by the presence of truncated layers and lenticular bedding demonstrating the effect of Baturin cycling, due to currentinduced, episodic sediment bypass. The formation of this condensed phosphatic bed, therefore, could have taken place along the distal-shelf environment, which is characterized by current-induced erosion, winnowing and very-low sediment accumulation rates. In this case, organic-rich sediments, strong coastal upwelling and low oxygen zones may be common where phosphorite formation occurs (e.g. continental margin), where apatite precipitation happened during early diagenesis in the upper few tens of centimetres of the sediments and/or with microbial cooperation (Fig. 13). The role of detrital input was proven and a mixed origin for apatite may be suggested where a hydrothermal fluid could also play a role in the crystallization.

The models above are supported by the known geological background because the host rock of the phosphorite of Pécsely formed in a pelagic-basin environment, while the bed rock of the phosphorite from Tata represents a deep bathyal-basin facies and the cover rock (the Tata Limestone Formation) formed in a sublitoral external shelf environment (Budai et al., 2017; Fülöp, 1954, 1964, 1975).

\section{Geological correlation possibilities}

The U-containing phosphorite occurrence in the Pécsely area seems to be a local phenomenon and cannot be correlated regionally with other occurrences. Only one other similar occurrence, though without $\mathrm{U}$ enrichment, is noted from the region, the 'Grenzbitumenzone' occurrence at Monte San Giorgio in the southern Alps (Bernasconi, 1994). This Middle Triassic zone is famous for its abundant fossil vertebrates; phosphogenesis took place there also, in fully anoxic sediments. Phosphatized organisms and coprolites occur in laminated, organic-rich sediments in this formation which are inferred to have originated below an anoxic lower water mass, separated from an upper oxygenated water mass by a mid-water redox boundary (Bernasconi, 1994).

The Cretaceous phosphorite nodules of Tata have more correlation possibilities. Föllmi (2012) defined Early Cretaceous life and environment changes. The origin and evolution of Early Cretaceous OAEs and their sedimentological and geochemical expressions have been also discussed (e.g. Föllmi, 2012; Skelton et al., 2003). The Early Aptian Selli Episode is defined by a negative $\delta^{13} \mathrm{C}$ excursion, which is followed by a positive $\delta^{13} \mathrm{C}$ excursion, covering the Deshayesi and the Furcata Zones. This includes an important laminated, organic-rich mud level, which is known as 'Selli' in the Neotethys basin (Föllmi, 2012). Szives $(1999,2001)$ and Szives et al., (2007) investigated the ammonite fauna of Kálvária Hill at Tata. Based on these works we may conclude that, at least on a family level, the characteristic ammonite fauna (D. deshayesi) of the Selli Event occur in the area. It can be assumed, nevertheless, that the phosphorite nodule-containing condensed layers are genetically related to the Selli Event and thus are correlated with other Early Cretaceous phosphorite occurrences, which formed during this event, e.g. Col de la Plaine Morte area, central Switzerland (Föllmi and Gainon, 2008); Rohrbachstein, Plaine Morte and Luitere beds, Switzerland (Gainon, 2001); and the Hybla Formation, Sicily (Bellanca et al., 2002). 


\section{Economic importance of the phosphorite occurrences studied}

Phosphate rocks, as well as phosphorus and the heavy and light rare-earth elements are listed as critical raw materials in the EU; the occurrences studied here should be taken into consideration when evaluating CRM resources. In spite of this, information about the present occurrences was not available in the ProMine database (Cassard et al., 2012). Understanding the genesis of the two deposits contributes to our local economic, geological knowledge and the formation model may be applied in the geology of the correlated areas. The occurrences studied may not just be phosphorous resources; the REE contents of Tata and the $\mathrm{U}$ content in Pécsely may be greater than the average in phopshorites (Baturin and Kochenov, 2001). The causes of these enrichments may relate to OAEs as well as to the hydrothermal fluid input.

The known dimensions of the Tata occurrence are limited, however, and its economic importance is not significant, therefore. The Pécsely occurrence, however, is obviously more extensive, based on exploration trenches and adits (Kiss and Virágh, 1959), though exact dimensions and resource estimates are not available. Further research of the Pécsely occurrence is needed therefore, which is also proposed because of the epigenetic fluorite veins (Kiss and Virágh, 1959; Molnár et al., 2015) found in the area (fluorine is also listed as a CRM).

\section{Conclusions}

The Triassic and Cretaceous phosphorite occurrences studied are composed mostly of carbonatebearing fluorapatite (CFA) and are located at Pécsely and Tata in the TDMR. The environment of formation and the possible sources of $\mathrm{P}, \mathrm{U}$ and $R E E$ of both the laminated Triassic and the nodular Cretaceous phosphorites were studied here. The redox-sensitive element geochemistry suggests no detrital influence at Pécsely or at Tata. Both phosphorites formed under anoxic conditions. The inorganic Triassic phosphorite probably formed on a seamount, while the Cretaceous phosphorite can be interpreted as a continentalmargin phosphorite related to upwelling. The REE patterns and anomalies are different in the two formations. The diagenetic change in the $\mathrm{Ce}$ anomaly was detected in both areas, while the changeable Eu/Eu* anomaly, the super-chondritic $\mathrm{Y} / \mathrm{Ho}$ ratios and $\mathrm{Y}$ anomalies suggest predominant seawater, and an assumed, less important hydrothermal source for the CAF from Pécsely. In contrast, the relatively high $\mathrm{Eu} / \mathrm{Eu}^{*}$ ratios, the chondritic - super-chondritic Y/Ho ratios and positive $\mathrm{Y}$ anomalies suggest an obviously mixed origin for the CFA from Tata, where hydrothermal fluid may also play a role in the crystallization. The possible sources of $\mathrm{P}, \mathrm{U}$ and $R E E$ are also different at the two localities. The volcanic activity played a role in the formation of the phosphorite at Pécsely, but the monsoon-derived upwelling model may also have contributed to synsedimentary phosphorite formation. The dissolved $\mathrm{U}$ and $R E E$ may come from the Permian red sandstone along normal faults and/or from the volcanism. In the case of Tata, the source of $\mathrm{P}$ and $R E E$ was probably the deep waterdissolved phosphate and seawater REE content, though the high $\mathrm{Eu} / \mathrm{Eu}^{*}$ ratios suggest hydrothermal fluid input also (so far neither a local nor a regional source of hydrothermal fluid has been identified). It is also possible that these positive anomalies are partly related to the global Selli Event.

The Triassic seamount phosphorite is a local phenomenon while the Cretaceous continental margin phosphorite can be correlated with other phosphorite occurrences formed during the Selli Event. The models described are supported also by geological and palaeontological knowledge of the study regions.

\section{Acknowledgements}

Sándor Klaj, József Pálfy, Tamás Budai, János Haas, Andrea Mindszenty and István Szente (Budapest) are thanked for assistance during fieldwork and for constructive discussions during the research. The authors are very grateful to John Bowles (Guest Principal Editor of Mineralogical Magazine) and Eimear Deady for their constructive comments on the text and for language review, both contributing significantly to the development of the original manuscript. Reviews by Afat Serjani and an anonymous reviewer helped in finalizing the manuscript. The authors are grateful to Zsolt Bendö for helping with the SEM-EDS analyses and to Balázs Hargitai for helping in the sample preparation. The University Centre for Applied Geosciences (UCAG) is thanked for the access to the Eugen F. Stumpfl Electron Microprobe Laboratory (Leoben). The stable isotope analyses were supported by the Institute for Geological and Geochemical Research, Research Centre for Astronomy and Earth Sciences, Hungarian Academy of Sciences. 


\section{References}

Arthur, M.A. and Jenkyns, H.C. (1981) Phosphorites and paleoceanography. Oceanologica Acta, 4, 83-96.

Baksi, A.K. (1990) Timing and duration of MesozoicTertiary flood-basalt volcanism. EOS, Transactions American Geophysical Union, 71, 1835-1840.

Balla, Z., Gulácsi, Z., Maros, Gy. and Síkhegyi, F. (2009) Relief and Geological Map of the Pre Quaternary Complexes 1:10,000.

Bárdossy, Gy. (1982) Karst Bauxites: Bauxite Deposits on Carbonate Rocks. Elsevier Science Publishers, Amsterdam, $441 \mathrm{pp}$.

Baturin, G.N. (1982) Phosphorites on the Sea Floor. Developments in Sedimentology, 33. Elsevier, Amsterdam, 343 pp.

Baturin, G.N. and Kochenov, A.V. (2001) Uranium in phosphorites. Lithology and Mineral Resources, 36, 303-321.

Bau, M. (1996) Controls on the fractionation of isovalent trace elements in magmatic and aqueous systems: evidence from $\mathrm{Y} / \mathrm{Ho}, \mathrm{Zr} / \mathrm{Hf}$, and lanthanide tetrad effect. Contributions to Mineralogy and Petrology, 123, 323-333.

Bau, M. (1999) Scavenging of dissolved yttrium and rare earths by precipitating iron oxyhydroxide: experimental evidence for Ce oxidation, Y-Ho fractionation, and lanthanide tetrad effect. Geochemica et Cosmochemica Acta, 63, 67-77.

Bau, M. and Koschinsky, A. (2009) Oxidative scavenging of cerium on hydrous Fe oxide: Evidence from the distribution of rare earth elements and yttrium between Fe oxides and Mn oxides in hydrogenetic ferromanganese crusts. Geochemical Journal, 43, 37-47.

Bellanca, A., Erba, E., Neri, R., Premoli Silva, I., Sprovieri, M., Tremolada, F. and Verga, D. (2002) Palaeoceanographic significance of the Tethyan "Livello Selli" (early Aptian) from the Hybla Formation, northwestern Sicily: biostratigraphy and high-resolution chemostratigraphic records. Palaeogeography, Palaeoclimatology, Palaeoecology, 185, 175-196.

Bernasconi, S.M. (1994) Geochemical and Microbial Controls on Dolomite Formations in Anoxic Environments: A Case Study from the Middle Triassic (Ticino, Switzerland). Contributions to Sedimentology, Schweizerbart, Stuttgart, Germany, 109 pp.

Budai, T. (1993) Megyehegy dolomite formation. P. 278 in: Litostratigraphic Units of Hungary: Triassic (J. Haas, editor). Publication of the Geological Institute of Hungary, Budapest.

Budai, T. and Dosztály, L. (1990) Stratigraphic Problems Associated with the Ladinian formations in the Balaton Highland. Annual Report of the Geological Institute of Hungary, 1988, pp. 61-79.
Budai, T. and Haas, J. (1997) Triassic sequence stratigraphy of the Balaton Highland, Hungary. Acta Geologica Hungarica, 40, 307-335.

Budai, T. and Vörös, A. (1992) Middle Triassic history of the Balaton Highland: extensional tectonics and basin evolution. Acta Geologica Hungarica, 35, 237-250.

Budai, T. and Vörös, A. (2006) Middle Triassic platform and basin evolution of the Southern Bakony Mountains (Transdanubian Range, Hungary). Rivista Italiana di Paleontologia e Stratigrafia, 112, 359-371.

Budai, T, Császár, G., Csillag, G., Dudko, A., Koloszár, L. and Majoros, Gy. (1999) Geology of the Balaton Highland. Explanation to the Geological Map of the Balaton Highland, 1:50000. Special Publication of the Geological Institute of Hungary, Budapest, vol. 197, pp. 257.

Budai, T., Haas, J., Vörös, A. and Molnár, Zs. (2017) Influence of upwelling on the sedimentation and biota of the segmented margin of the western Neotethys: a case study from the Middle Triassic of the Balaton Highland. Facies, 63, 22.

Cassard, D., Bertrand, G., Maldan, F., Gaàl, G., Kaija, J., Angel, J.M., Arvanitidis, N., Ballas, D., Billa, M., Christidis, C. et al. (2012) ProMine pan-European Mineral Deposit database: a new dataset for assessing primary mineral resources in Europe. In: Workshop on: Mineral Resources Potential Maps: a Tool for Discovering Future Deposits, 12th-14th March 2012, Nancy, France.

Choi, S.-G., Kim, S.T. and Lee, J.G. (2003) Stable isotope systematics of Ulsan Fe-W skarn deposit, Korea. Journal of Geochemical Exploration, 78-79, 601-606.

Coccioni, R., Luciani, V. and Marsili, A. (2006) Cretaceous oceanic anoxic events and radially elongated chambered planktonic foraminifera: paleoecological and paleoceanographic implications. Palaeogeography, Palaeoclimatology, Palaeoecology, 235, 66-92.

Cros, E. and Szabó, I. (1984) Comparison of the Triassic volcanogenic formations in Hungary and in the Alps. Paleogeographic criteria. Acta Geologica Hungarica, 27, 265-276.

Császár, G. (1995) An overview of the Cretaceous research in the Gerecse Mountains and the Vértes Foreland. General Geological Review, 27, 133-152.

Csontos, L. and Vörös, A. (2004) Mesozoic plate tectonic reconstruction of the Carpathian region. Palaeogeography, Palaeoclimatology, Palaeoecology, 210, 1-56.

De Wever, P., O’Dogherty, L. and Goričanc, Š. (2014) Monsoon as a cause of radiolarite in the Tethyan realm. Comptes Rendus Geoscience, 346, 287-297.

Dunkl, I., Mikes, T., Simon, K. and von Eynatten, H. (2008) Brief introduction to the Windows program Pepita: data visualization, and reduction, outlier rejection, 
calculation of trace element ratios and concentrations from LA-ICP-MS data. Pp. 334-340 in: Laser ablation ICP-MS in the Earth Sciences: Current practices and outstanding issues (P. Sylvester, editor), Mineralogical Association of Canada, Short Course, 40.

EC (European Commission) (2014) On the review of the list of critical raw materials for the EU and the implementation of the Raw Materials Initiative. http:// eur-lex.europa.eu/legal-content/EN/TXT/PDF/?uri= CELEX:52014DC0297\&from=EN. Accessed 9 December 2016.

EC (European Commission) (2015) Report on Critical Raw Materials for the EU. Critical Raw Materials Profiles. http://ec.europa.eu/DocsRoom/documents/ 11911/attachments/1/translations. Accessed 9 December 2016.

Föllmi, K.B. (1996) The phosphorus cycle, phosphogenesis and marine phosphate-rich deposits. EarthScience Reviews, 40, 55-124.

Föllmi, K.B. (2012) Early Cretaceous life, climate and anoxia. Cretaceous Research, 35, 230-257.

Föllmi, K.B. and Gainon, F. (2008) Demise of the northern Tethyan Urgonian carbonate platform and subsequent transition towards pelagic conditions: the sedimentary record of the Col de la Plaine Morte area, central Switzerland. Sedimentary Geology, 205, $142-159$.

Főzy, I. (editor) (2012) Jurassic (Lithostratigraphic Units of Hungary). Publication of the Geological Society of Hungary, Budapest, 235 pp.

Főzy, I. (editor) (2013) Late Jurassic-Early Cretaceous Fauna, Biostratigraphy, Facies and Deformation History of the Carbonate Formations in the Gerecse and Pilis Mountains (Transdanubian Range, Hungary). Geolitera, Szeged, Hungary, 422 pp.

Frei, D. and Gerdes, A. (2009) Precise and accurate in situ $\mathrm{U}-\mathrm{Pb}$ dating of zircon with high sample throughput by automated LA-SF-ICP-MS. Chemical Geology, 261, 261-270.

Fülöp, J. (1954) A Examen géologique de la motte mésozoique de Tata. Bulletin of the Hungarian Geological Society, 84, 309-325.

Fülöp, J. (1964) Lower Cretaceous (Berriasian-Aptian) formations of the Bakony Mountains. Geologica Hungarica Series Geologica, 13, 1-94.

Fülöp, J. (1975) The Mesozoic basement horst blocks of Tata. Geologica Hungarica: Series Geologica, 16, 229.

Fülöp, J., Brezsnyánszy, K. and Haas, J. (1987) The new map of basin basement of Hungary. Acta Geologica Hungarica, 30, 3-20.

Gainon, F. (2001) Etude géologique dans la région du Rawil: Cartographie et étude stratigraphique et sédimentologique des Couches à Orbitolines supérieures et de la Formation de Garschella. Unpublished diploma thesis, University of Neuchâtel, Switzerland, 90 pp.
Gawlick, H.J., Frisch, W., Vecsei, A., Steiger, T. and Böhm, F. (1999) The change from rifting to thrusting in the Northern Calcareous Alps as recorded in Jurassic sediments. Geologische Rundschau, 87, 644-657.

Glenn, C.R., Follmi, K.B., Riggs, S.R., Baturin, G.N., Grimm, K.A., Trappe, J., Abed, A.M., Galliolivier, C., Garrison, R.E., Ilyin, A.V. et al. (1994) Phosphorus and phosphorites - Sedimentology and environments of formation. Eclogae Geoogica Helvetica, 87, 747-788.

Gromet, P.L., Dymek, P.F., Haskin, L.A. and Korotev, R. L. (1984) The North American shale composite: Its composition, major and minor element characteristics. Geochimica et Cosmochimica Acta, 48, 2469-2482.

Győri, O., Haas, J. and Hips, K. (2014) Dolomitization of the Lower Triassic shallow-water, mixed siliciclasticcarbonate rocks from the Transdanubian Range, Hungary. P. 273 in: 19th International Sedimentological Congress Abstract Book.

Haas, J. and Budai, T. (1995) Upper Permian-Triassic facies zones in the Transdanubian Range. Rivista Italiana di Paleontologia e Stratigrafia, 101, 249-266.

Haas, J., Jocháné Edelényi, E., Gidai, L., Kaiser, M., Kretzoi, M. and Oravecz, J. (1985) Geology of the Sümeg area. Geologica Hungarica: Series Geologica, 20, 353.

Haas, J., Kovács, S., Krystyn, L. and Lein, R. (1995) Significance of Late Permian-Triassic facies zones in terrane reconstructions in the Alpine-North Pannonian domain. Tectonophysics, 242, 19-40.

Haas, J., Götz, A. and Pálfy, J. (2010) Late Triassic to Early Jurassic palaeogeography and eustatic history in the NW Tethyan realm: New insights from sedimentary and organic facies of the Csővár Basin (Hungary). Palaeogeography, Palaeoclimatology, Palaeoecology, 291, 456-468.

Haskin M.A. and Haskin L.A. (1966) Rare Earth in Europian shales: A redetermination. Science, 154, 507-509.

Jackson, S., Pearson, N., Griffin, W. and Belousova, E. (2004) The application of laser ablation-inductively coupled plasma-mass spectrometry to in situ U-Pb zircon geochronology. Chemical Geology, 211, 47-69.

Jones, B. and Manning, D.A.C. (1994) Comparison of geochemical indices used for the interpretation of palaeo-redox conditions in ancient mudstones. Chemical Geology, 111, 111-129.

Kázmér, M. and Kovács, S. (1985) Permian-Paleogene paleogeography along the eastern part of the InsubricPeriadriatic lineament system: evidence for continental escape of the Bakony-Drauzug unit. Acta Geologica Hungarica, 28, 71-84.

Kimura, H. and Watanabe, Y. (2001) Ocean anoxia at the Precambrian-Cambrian boundary. Geology, 29, 995-998. 
Kiss, J. and Virágh, K. (1959) A uranium-bearing phosphatic rock in the Triassic of the Balaton Uplands around Pécsely. Bulletin of the Hungarian Geological Society, 89, 85-97.

Knauer, J., Deák, M. and Czabalay, L. (1972) Cretaceous, Aptian. Pp. 118-125 in: L-33-XH. Veszprém, Explanation of the Geological Map Series of Hungary, 1:200000 (M. Deák, editor), Publication of the Geological Institute of Hungary.

Knudsen, A.C. and Gunter, M.E. (2002) Sedimentary Phosphorites - An Example: Phosphoria Formation, Southeastern Idaho, U.S.A. Pp. 363-389 in: Phosphates: Geochemical, Geobiological, and Materials Importance, (M.J. Kohn, J. Rakovan, and J.M. Hughes, editors). Reviews in Mineralogy and Geochemistry, 48, Mineralogical Society of America, Washington, D.C.

Kolodny, Y. and Luz, B. (1992) Phosphate deposits, formation and diagenetic history. Pp. 69-122 in: Isotopic Signatures and Sedimentary Records (N. Clauer and S. Chaudhuri, editor). Springer-Verlag, New York/Heidelberg.

Korpás, L. (1981) Oligocene-Lower Miocene formations of Transdanubian Range. Annual Report of the Geological Institute of Hungary, 64, p. 140.

Korte, C., Kozur, H.W. and Veizer, J. (2005) $\delta^{13} \mathrm{C}$ and $\delta^{18} \mathrm{O}$ values of Triassic brachiopods and carbonate rocks as proxies for coeval seawater and palaeotemperature. Palaeogeograpgy, Palaeoclimatology, Palaeoecology, 226, 287-306.

Koschinsky, A., Stascheit, A., Bau, M. and Halbach, P. (1997) Effects of phosphatization on the geochemical and mineralogical composition of marine ferromanganese crusts. Geochimica et Cosmochimica Acta, 61, 4079-4094.

Kovács, S. (1982) Problems of the "Pannonian Median Massif" and the distribution of Late Paleozoic-Early Mesozoic isotopic zones. Geologische Rundshau, 71, 617-640.

Langmuir, D. (1978) Uranium solution-mineral equilibria at low temperatures with applications to sedimentary ore deposits. Geochimica et Cosmochimica Acta, 42, 547-569.

Larson, R.L. (1991) Geological consequence of superplumes. Geology, 19, 963-966.

Larson, R.L. and Erba, E. (1999) Onset of the midCretaceous greenhouse in the Barremian-Aptian: Igneous events and the biological, sedimentary, and geochemical responses. Paleoceanography, 14, 663-678.

Lelkes, Gy. (1990) Microfacies study of the Tata Limestone Formation (Aptian) in the northern Bakony Mountains, Hungary. Cretaceous Research, 11, 273-287.

Ludwig, K.R. (2012) User's manual for Isoplot 3.75: A geochronological Toolkit for Microsoft Excel. Berkeley Geochronology Center Special Publication, 4, 70 pp.
Majoros, Gy. (1980) Problems of Permian sedimentation in the Transdanubian Central Mountains: a palaeogeographic model and some conclusions. Bulletin of the Hungarian Geological Society, 110, 323-341.

McArthur, J.M. and Walsh, J.N. (1984) Rare-earth geochemistry of phosphorites. Chemical Geology, 47, 191-220.

McLennan, S.M. (1989) Rare earth elements in sedimentary rocks; influence of provenance and sedimentary processes. Pp. 169-200 in: Geochemistry and Mineralogy of Rare Earth Elements (B.R. Lipin and G.A. McKay, editors). Reviews in Mineralogy, Vol. 21. Mineralogical Society of America, Washington, D.C.

Meneghini, F., Botti, F., Aldega, L., Boschi, C., Corrado, S., Marroni, M. and Pandolfi, L. (2012) Hot fluid pumping along shallow-level collisional thrusts: The Monte Rentella Shear Zone, Umbria Apennine, Italy. Journal of Structural Geology, 37, 36-52.

Michard, A. (1989) Rare Earth element systematics in hydrothermal fluids. Geochimica et Cosmochimica Acta, 53, 745-750.

Mindszenty, A. (1984) The lithology of some Hungarian bauxites - a contribution to the palaeogeographic reconstruction. Acta Geologica Hungarica, 27, 441-455.

Molnár, Z., Kiss, B.G., Dunkl, I., Váczi, T., Zaccarini, F. and Dódony, I. (2015) Genetic study of the fluorite veins of Pécsely, (Balaton Highland, Transdanubian Mountain Range, NW Hungary). Pp. 146-147 in: XXIII. European Current Research On Fluid Inclusions Conference, Extended Abstracts Volume.

Morad, S. and Felitsyn, S. (2001) Identification of primary Ce-anomaly signatures in fossil biogenic apatite: Implication for the Cambrian oceanic anoxia and phosphogenesis. Sedimentary Geology, 143, 259-264.

Morford, J.L. and Emerson, S. (1999) The geochemistry of redox sensitive trace metals in sediments. Geochemica et Cosmochimica Acta, 63, 1735-1750.

Nozaki, Y., Zhang, J. and Amakawa, H. (1997) The fractionation between $\mathrm{Y}$ and $\mathrm{Ho}$ in the marine environment. Earth and Planetary Science Letters, 148, 329-340.

Paces, J.B. and Miller, J.D. (1993) Precise U-Pb ages of Duluth Complex and related mafic intrusions, northeastern Minnesota: geochronological insights into physical, petrogenetic, paleomagnetic and tectonomagmatic processes associated with the $1.1 \mathrm{Ga}$ midcontinent rift system. Journal of Geophysical Research, 98, 13997-14013.

Palache, C., Berman, H. and Frondel, C. (1951) Dana's System of Mineralogy, 7th edition. v. II, pp. 879-889.

Pálfy, J., Parrish, R.R. and Vörös, A. (2003) Mid-Triassic integrated $\mathrm{U}-\mathrm{Pb}$ geochronology and ammonoid biochronology from the Balaton Highland (Hungary). Journal of the Geological Society, 160, 271-284. 
Piper, D.Z. (1994) Seawater as the source of minor elements in black shales, phosphorite and other sedimentary rocks. Chemical Geology, 114, 95-114.

Pocsai, T. and Csontos, L. (2006) Late Aptian-Early Albian syn-tectonic facies pattern of the Tata Limestone Formation (Transdanubian Range, Hungary). Geologica Carpathica, 57, 15-27.

Pufahl, P.K. and Groat, L.A. (2017) Sedimentary and igneous phosphorite deposits: formation and exploration: an invited paper. Economic Geology, 112, 483-516.

Rampino, M.R. and Stothers, R.B. (1988) Flood basalt volcanism during the past 250 million years. Science, 241, 663-668.

Rimmer, S.M. (2004) Geochemical paleoredox indicators in Devonian-Mississippian black shales, Central Appalachian Basin (USA). Chemical Geology, 206, 373-391.

Schmid, S., Bernoulli, D., Fügenschuh, B., Matenco, L., Schefer, S., Schuster, R., Tischler, M. and Ustaszewski, K. (2008) The Alpine-Carpathian-Dinaridic orogenic system: correlation and evolution of tectonic units. Swiss Journal of Geosciences, 101, 139-183.

Shields, G. and Stille, P. (2001) Diagenetic constraints on the use of Cerium anomalies as palaeoseawater redox proxies: an isotopic and REE study of Cambrian phophorites. Chemical Geology, 175, 29-48.

Sidó, M. (1975) The foraminifera of Tata Formation (Upper Aptian). Bulletin of the Hungarian Geological Society, 105, 155-187.

Skelton, P.W., Spicer, R.A., Kelley, S.P. and Gilmour, I. (2003) The Cretaceous World. Cambridge University Press, Cambridge, UK, 360 pp.

Sláma, J., Košler, J., Condon, D.J., Crowley, J.L., Gerdes, A., Hanchar, J.M., Horstwood, M.S.A., Morris, G.A., Nasdala, L., Norberg, N. et al. (2008) Plešovice zircon - A new natural reference material for $\mathrm{U}-\mathrm{Pb}$ and $\mathrm{Hf}$ isotopic microanalysis. Chemical Geology, 249, 1-35.

Spötl, C. and Wennemann, T.W. (2003) Continuous-flow isotope ratio mass spectrometric analysis of carbonate minerals. Rapid Communications in Mass Spectrometry, 17, 1004-1006.

Szives, O. (1999) The palaeobiological evaluation of the ammonites of the Tata limestone Formation (Aptian), Hungary. Bulletin of the Hungarian Geological Society, 129, 179-190.

Szives, O. (2001) A taphonomic interpretation of the Aptian-Lower Campanian ammonites of Tata, Hungary. Bulletin of the Hungarian Geological Society, 131, 343-351.

Szives, O. (2008) Two new species of Constrictoceras nov. gen. (Ammonoidea) from the Early Cretaceous (Aptian) of Hungary. Geobios, 41, 297-305.

Szives, O., Csontos, L., Bujtor, L. and Főzy, I. (2007) Aptian-Campanian ammonites of Hungary. Geologica
Hungarica, Series Palaeontologica, Fasciculus, 57, 145.

Tari, G., Báldi, T. and Báldi-Beke, M. (1993) Paleogene retroarc flexural basin beneath the Neogene Pannonian Basin: A geodynamic model. Tectonophysics, 226, 433-455.

Taylor, S.R. and McLennan, S.M. (1985) The Continental Crust: Its Composition and Evolution. Blackwell Scientific Publications, London, pp. 57-72.

Tribovillard, N., Algeo, T.J., Lyons, T. and Riboulleau, A. (2006) Trace metals as paleoredox and paleoproductivity proxies: An update. Chemical Geology, 232, 12-32.

Tsikos, H., Karakitsios, V., van Breugel, Y., WalsworthBell, B., Bombardière, L., Petrizzo, M.R., SinningheDamsté, J.S., Schouten, S., Erba, E., Premoli Sliva, I. et al. (2004) Organic-carbon deposition in the Cretaceous of the Ionian Basin, NW Greece: the Paquier event (OAE1b) revisited. Geological Magazine, 141, 401-416.

Tyson, R.V. and Pearson, T.H. (1991) Modern and ancient continental shelf anoxia: An overview. Pp. 1-24 in: Modern and Ancient Continental Shelf Anoxia (R.V. Tsyson and T.H. Pearson, editors). Special Publications, 58, Geological Society, London.

Vadász, E. (1946) Die geologische entwicklung und das Alter der ungarishen Bauxitvorkommen. Annual Report of the Geological Institute of Hungary, 37, pp. 235-286.

Vörös, A. and Pálfy, J. (1989) The Anisian/Ladinian boundary in the Vászoly section (Balaton Highland, Hungary). Fragmenta Mineralogica et Palaentologica, 14, 17-27.

Vörös, A., Budai, T., Lelkes, Gy., Monostori, M. and Pálfy, J. (1997) Middle Triassic basin evolution of the Balaton Highland (Hungary) based on sedimentological and paleoecological studies. Bulletin of the Geological Society of Hungary, 127, 145-177.

Wiedenbeck, M., Allé, P., Corfu, F., Griffin, W.L., Meier, M., Oberli, F., von Quadt, A., Roddick, J.C. and Spiegel, W. (1995) Three natural zircon standards for $\mathrm{U}-\mathrm{Th}-\mathrm{Pb}, \mathrm{Lu}-\mathrm{Hf}$, trace element and REE analyses. Geostandards Newsletters, 19, 1-23.

Wignall, P.B. and Twitchett, R.J. (1996) Oceanic anoxia and the end Permian mass extinction. Science, 272, 1155-1158.

Wright, J., Seymour, R. and Shaw, H.F. (1984) REE and $\mathrm{Nd}$ isotopes in conodont apatite: variation with geological age and depositional environment. Pp. 325-340 in: Conodont Biofacies and Provincialism (D.L. Clark, editor). Special Papers 196, Geological Society of America, Boulder, Colorado, USA.

Zanin, Y. and Zamirailova, A. (2009) Rare earth elements in supergene phosphorites. Geochemistry International, 47, 282-296. 